\title{
A evolução histórica da ergonomia no mundo e seus pioneiros
}

\author{
José Carlos Plácido da Silva \\ Luís Carlos Paschoarelli \\ (orgs.)
}

SILVA, JCP., and PASCHOARELLI, LC., orgs. A evolução histórica da ergonomia no mundo e seus pioneiros [online]. São Paulo: Editora UNESP; São Paulo: Cultura Acadêmica, 2010. 103 p. ISBN 978-85-7983-120-1. Available from SciELO Books 〈http://books.scielo.org $>$.

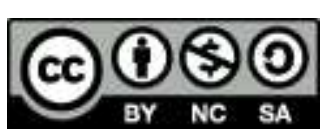

All the contents of this work, except where otherwise noted, is licensed under a Creative Commons Attribution-Non Commercial-ShareAlike 3.0 Unported.

Todo o conteúdo deste trabalho, exceto quando houver ressalva, é publicado sob a licença Creative Commons Atribuição Uso Não Comercial - Partilha nos Mesmos Termos 3.0 Não adaptada.

Todo el contenido de esta obra, excepto donde se indique lo contrario, está bajo licencia de la licencia Creative Commons Reconocimento-NoComercial-CompartirIgual 3.0 Unported. 


\section{A eVOluÇÃo HISTÓRICA DA ERGONOMIA NO MUNDO E SEUS PIONEIROS}


CONSELHO EDITORIAL ACADÊMICO

Responsável pela publicação desta obra

\author{
João Candido Fernandes \\ João Roberto Gomes de Faria \\ Luiz Gonzaga Campos Porto \\ Marizilda dos Santos Menezes
}




\title{
JOSÉ CARLOS PLÁCIDO DA SILVA LUIS CARLOS PASCHOARELLI \\ (Orgs.)
}

\author{
A evolução \\ HISTÓRICA DA \\ ERGONOMIA NO \\ MUNDO E SEUS \\ PIONEIROS
}

CULTURA

$\frac{\text { ACADÊMICA }}{\varepsilon d i t o n a}$ 
(C) 2010 Editora UNESP

\section{Cultura Acadêmica}

Praça da Sé, 108

01001-900 - São Paulo - SP

Tel.: (0xx11) 3242-7171

Fax: (0xx11) 3242-7172

www.editoraunesp.com.br

feu@editora.unesp.br

CIP - Brasil. Catalogação na fonte

Sindicato Nacional dos Editores de Livros, RJ

\section{E94}

A evolução histórica da ergonomia no mundo e seus pioneiros / José Carlos Plácido da Silva, Luís Carlos Paschoarelli (orgs.). - São Paulo : Cultura Acadêmica, 2010.

il.

Inclui bibliografia

ISBN 978-85-7983-120-1

1. Ergonomia. 2. Ergonomia - História. 3. Desenho industrial. I. Silva, José Carlos Plácido da. II. Paschoarelli, Luís Carlos.

11-0143.

CDD: 620.82

CDU: 7.05

Este livro é publicado pelo Programa de Publicações Digitais da Pró-Reitoria de Pós-Graduação da Universidade Estadual Paulista "Júlio de Mesquita Filho" (UNESP)

Editora afiliada:

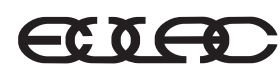

Asociación de Editoriales Universitarias de América Latina y el Caribe

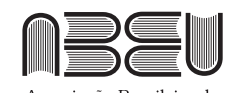

Associação Brasileira de Editoras Universitárias 


\section{SUMÁRIO}

Apresentação 9

1 Os estudos de Leonardo da Vinci e sua ação precursora na ergonomia 11

Marcos José Alves de Lima

Ana Clara Lauar

Verena Ferreira Tidei de Lima

José Carlos Plácido da Silva

Luis Carlos Paschoarelli

2 Contribuições científicas de Bernard Forest de Bélidor para o estudo e a organização do trabalho 17

Danilo Corrêa Silva

João Carlos Riccó Plácido da Silva

Luciane do Prado Carneiro

José Carlos Plácido da Silva

Luis Carlos Paschoarelli

3 Patissier: fragmentos de uma contribuição à Ergonomia 27

Ana Cláudia Scarpim

Cláudio Vidrih Ferreira

José Carlos Plácido da Silva

Luis Carlos Paschoarelli 
4 Da organização científica à Ergonomia:

a contribuição de Frederick Wisnslow Taylor 37

Bruno Montanari Razza

Cristina do Carmo Lucio

José Carlos Plácido da Silva

Luis Carlos Paschoarelli

5 A arte do trabalho: Jules Amar 49

Silvana Aparecida Alves

Frederico Reinaldo Corrêa de Queiroz

José Carlos Plácido da Silva

Luis Carlos Paschoarelli

6 A origem da Ergonomia na Europa: contribuições específicas de Inglaterra e França 55

Ana Clara Fernandes Láuar

Marcos José Alves de Lima

Verena Ferreira Tidei de Lima

José Carlos Plácido da Silva

Luis Carlos Paschoarelli

7 Desenvolvimento da Ergonomia na Rússia (ex-URSS):

estudos aplicados à indústria e à aeronáutica 61

João Carlos Riccó Plácido da Silva

Danilo Corrêa Silva

Luciane do Prado Carneiro

José Carlos Plácido da Silva

Luis Carlos Paschoarelli

8 Origem da Human Factors nos Estados Unidos da América 73

Alexandre Perussi

Frederico Queiroz

Rafaela Santana Balbi

José Carlos Plácido da Silva

Luis Carlos Paschoarelli 
9 Ergonomia na America Latina: iniciativas, estabelecimento e consolidação 81

Carlos Eduardo Lins Onofre Ana Cláudia Scarpim Cláudio Vidrih Ferreira José Carlos Plácido da Silva Luis Carlos Paschoarelli

10 Trajetória da Ergonomia no Brasil: aspectos expressivos da aplicação em design 91

Cristina do Carmo Lucio

Silvana Aparecida Alves

Bruno Montanari Razza José Carlos Plácido da Silva Luis Carlos Paschoarelli 



\section{ApresentaÇÃo}

Os conceitos e aplicações da ergonomia estão em constante discussão no âmbito acadêmico, caracterizando um corpus de conhecimento de grande expressividade para a própria ciência ergonômica e demais áreas tecnológicas correlatas, a saber: engenharias, design, arquitetura, entre outras.

Mas entre as demandas para ampliar as análises em torno dessa disciplina apresenta-se sua evolução histórica, a qual está completa de controvérsias e discussões.

De fato, há ainda uma grande dificuldade em relatar suas etapas históricas dentro do âmbito geográfico e a participação de seus precursores nessas fases.

O propósito dessa coletânea foi o de reunir os estudos realizados pelos alunos da linha de pesquisa ergonomia, associados ao Laboratório de Ergonomia e Interfaces (LEI), no Programa de Pósgraduação em Design da Faculdade de Arquitetura, Artes e Comunicação da Universidade Estadual Paulista, e apresentar subsídios para ampliação da discussão e reflexão evolutiva da ergonomia.

Os estudos ora apresentados preenchem lacunas ainda existentes dentro da ergonomia e procuram estabelecer um elo de ligação para a continuidade futura das pesquisas na área. 



\title{
1 \\ Os ESTUdos de LEONARDO DA VINCI E SUA AÇÃO PRECURSORA NA ERGONOMIA
}

\author{
Marcos José Alves de Lima \\ Ana Clara Lauar \\ Verena Ferreira Tidei de Lima \\ José Carlos Plácido da Silva \\ Luis Carlos Paschoarelli
}

\section{Introdução}

O estudo da ergonomia é fascinante e carrega consigo o poder de desvendar uma série de informações ainda pouca exploradas, entre elas destaca-se a investigação dos precursores dessa ciência, portanto estabelecer que ela seja uma ciência nova conduz a uma afirmação equivocada. No entanto, sua origem oficial é estabelecida quando da oficialização pelo engenheiro inglês Kenneth Frank Hywel Murrell da primeira sociedade de ergonomia do mundo, a Ergonomic Research Society, no ano de 1949.

O texto resgata e apresenta as contribuições que Leonardo da Vinci como um dos precursores dessa área se apresenta, atribuindo principalmente às suas práticas o caráter de ação precursora da ergonomia.

\section{Biografia}

Leonardo nasceu em 1452 na aldeia de Vinci, próxima a Florença, na Itália. Antes dos 18 anos, tornou-se aprendiz do artista (pintor e escultor) florentino Andrea Verrochio, em sua oficina, 
e não demorou em ser membro da Compagnia di San Luca dos pintores florentinos. Em suas primeiras obras independentes e mesmo nas contribuições realizadas a seu mestre Verrochio, já eram perceptíveis algumas peculiaridades que tornar-se-iam características notáveis de suas obras: jogos de luz, organização espacial, perspectiva e tridimensionalidade. Tais características acompanharam Leonardo em suas principais obras, desde os rascunhos até as pinturas e esculturas.

Habituado no Renascimento, época em que o homem era tido como o centro do universo e a ciência constituía-se basicamente em matemática e medicina, Leonardo incorporou ao máximo o "homem universal" (ou uomo universale). Visionário, curioso e ávido por saber nos mais diversos campos, como o da pintura, arquitetura, escultura, engenharia, natureza (física e humana), anatomia e fisionomia (animal e humana), entre outros.

Por volta de 1490, fundou a "achademia vinciana". Muitos pintores juntaram-se a ele nesse espaço versátil e pluridisciplinar, no qual implantou uma metodologia de ensino de arte que era baseada no redesenho de obras de mestres anteriores, no estudo formal e proporcional de corpos naturais, no desenho e, por último, no uso de cores. Munari (2008) afirma que "criatividade não significa improvisação sem método: dessa maneira só se cria confusão, e planta-se nos jovens a ilusão de que artistas devem ser livres e independentes". Essa visão aponta para uma forte característica do trabalho de Leonardo da Vinci, que era a habilidade de um agir formal e sistemático.

Viveu em diversos lugares além de Florença, Roma, Veneza e Milão. Em seus últimos anos de vida viveu na França, no castelo de Cloux, um presente dado pelo rei, onde veio a falecer em 1519.

Entre suas obras e estudos, alguns dos mais conhecidos são: "A Última Ceia”, afresco pintado em 1498 no convento de Santa Maria delle Grazie, em Milão; "Mona Lisa" ou "La Gioconda", iniciada em 1502 e finalizada cerca de três anos mais tarde, atualmente exposta no Louvre, em Paris; "O Homem Vitruviano", um redesenho dos estudos de Marcus Vitruvius Pollio. 


\section{Atitudes precursoras}

Embora Leonardo se intitulasse um homem sem estudos, Márias (1997) sustenta a ideia de que ele tenha sido precisamente o inventor das ciências modernas, fundamentadas num método que se basearia na experiência e na matemática.

Para Leonardo, o verdadeiro saber provinha de experiências, das observações e de invenções. Aplicou rigidamente uma metodologia em seus projetos, na sua arte e nos seus estudos. Os estudos anatômicos e fisiológicos foram certamente suas principais contribuições à ergonomia. Cada obra era dotada de uma análise criteriosa e do estudo prévio de todos os seus elementos, como luz, sombra e movimento, e o sempre presente naturalismo, em cujas obras exigiam de Leonardo uma observação rigorosa e minuciosa do homem, como, por exemplo, seus volumes, relevos e anatomia. A observação externa dos corpos já lhe havia fornecido todo o conhecimento possível para que executasse sua arte, quando se voltou então para a dissecação e estudo da anatomia dos corpos, de tal forma era possível compreender as forças e estruturas internas que possibilitavam uma determinada aparência externa da figura humana. Alguns de seus cadernos de estudos apresentavam mais de 600 esboços sobre o tema.

Entre esses estudos, destaca-se a figura do homem vitruviano de Marcus Vitruvius Pollio, redesenhada por Leonardo da Vinci. Marcus Vitruvius Pollio (75-25 a.C.) foi o autor do único tratado de arquitetura da Antiguidade sobrevivente até os dias de hoje. Descreveu que o ponto de partida da arquitetura para a construção de ambientes deveria ser a natureza e suas proporções perfeitas. Compôs uma imensa obra que visava analisar os variados elementos da arquitetura, tanto de caráter civil como militar.

A principal relevância da ação de Leonardo ao juntar o homem canônico do quadrado e da circunferência, em seus centros geradores e clássicos em uma só figura, foi manter o homem fixo em um lugar, girar ou articular seus membros inferiores e superiores ainda conectados ao tronco e, como é característica dos precursores 
e empreendedores, pensar diferente e alterar a posição das formas, o quadrado e a circunferência, neste caso, o que viria a ser um princípio da ergonomia, isto é, o posto de trabalho, o ambiente, a roupa e as questões periféricas devem se adaptar ao homem, e não o homem a eles.

Leonardo combinou em um mesmo desenho o homem inserido no círculo e no quadrado, promovendo estudos acerca das dimensões e movimentos humanos. Atualmente, o conhecimento das formas e medidas do corpo aplicado em projetos é denominado antropometria (Boueri, 2008).

Outros arquitetos e artistas também estudaram com esmero as relações e proporções canônicas, contudo sobrepunham o círculo e o quadrilátero, alterando as divinas medidas do homem e provocando a distorção da figura humana neles contida.

De acordo com Martins (2008), o corpo humano é o ponto de partida para o projeto de produto. Dessa forma, os estudos minuciosos de Leonardo acerca da anatomia humana, principalmente seu estudo sobre "O Homem Vitruviano", são precursores essenciais do estudo da antropometria e da ergonomia.

Como engenheiro inventivo e intuitivo, também é relevante destacar os fatores humanos em seus projetos, como, por exemplo, o projeto de uma catapulta gigante que era operada por um homem, um exemplo típico da descrição homem-máquina. Outro exemplo significativo é o da apresentação de uma máquina voadora em que se observa que a posição do homem obedece rigorosamente àquela assumida ainda nos dias de hoje.

Cada um de seus projetos, desenhos e rascunhos, que hoje tem valor e status de obra de arte, vinha repleto de anotações e observações técnicas e minuciosas, bem como resultados esperados quando se tratava de projetos bélicos. Tanto é que em 2004 o Museu de História da Ciência, em Florença, na Itália, colocou em exibição o primeiro "automóvel" construído com base nos esboços realizados do famoso livro de anotações de Da Vinci.

O "carro" de aparência primitiva se locomove com a ajuda de molas no lugar de combustível, e foi provavelmente planejado para 
produzir efeitos especiais em eventos nobres. Mas, de acordo com os especialistas, foi o primeiro veículo autopropulsor do mundo.

O "automóvel" não é a primeira e única invenção das descobertas verificadas nos manuscritos de Leonardo da Vinci, constatamse ainda as máquinas voadoras, helicópteros, submarinos, tanques militares e bicicletas.

\section{Discussão e considerações finais}

O foco central da curiosidade científica de Leonardo da Vinci era o homem e o seu entorno, considerando os seus pormenores e as mais amplas relações, demonstrando claramente a preocupação central dos fatores humanos.

Em seus estudos e projetos, as máquinas e suas funções se ajustavam ao homem, facilitando a execução de diversas ações.

A releitura e o redesenho de "O Homem Vitruviano" realizados por ele são uma referência significativa nos estudos da antropometria e da ergonomia, demonstrando inclusive a importância de que os projetos levem em consideração essas relações.

\section{Referências bibliográficas}

BOUERI, J. J. Sob medida: antropometria, projeto e modelagem. In: PIRES, D. B. (Org.). Design de moda: olhares diversos. Barueri: Estação das Letras e Cores Editora, 2008.

MÁRIAS, F. Leonardo da Vinci: grandes mestres da pintura clássica. Lisboa: Editorial Estampa, 1997.

MARTINS, S. B. Ergonomia e moda: repensando a segunda pele. In: PIRES,

D. B. (Org.). Design de moda: olhares diversos. Barueri: Estação das Letras e Cores Editora, 2008, p.319-336.

MUNARI, B. Das coisas nascem coisas. São Paulo: Martins Fontes, 1998. 



\title{
2 \\ Contribuições Científicas de BeRnaRd FOREST DE BÉLIDOR PARA O ESTUDO E A ORGANIZAÇÃO DO TRABALHO
}

\author{
Danilo Corrêa Silva \\ João Carlos Riccó Plácido da Silva \\ Luciane do Prado Carneiro \\ José Carlos Plácido da Silva \\ Luis Carlos Paschoarelli
}

\section{Introdução}

Desde a Antiguidade a forma de trabalho é motivo de estudos e de preocupações para a sociedade. A simplificação e a preparação do trabalho provavelmente foram de grande importância, sem as quais possivelmente não existiriam as grandiosas realizações dos egípcios, persas, gregos e romanos.

Possivelmente o primeiro estudo realizado sobre o assunto foi o do general e filósofo ateniense Xenofonte, por volta de 427 a 355 a.C., que preconizou a divisão do trabalho de maneira que cada operário efetuasse sempre em uma só operação, durante a fabricação de coturnos da armada grega.

O estudo do trabalho continuou com Leonardo da Vinci (entre 1452 e 1519), que se destacou por suas ideias nesse campo. Suas anotações continham ideias de organização racional de trabalho, em que indicam a divisão das atividades profissionais, a mensuração do tempo e o uso de quadros visuais de ordenação e de lançamento, semelhantes aos atuais quadros de planejamento.

Em meados do século XVII, verifica-se que foram determinadas e estabelecidas algumas tarefas diárias que poderiam ser exigi- 
das dos trabalhadores. Além disso, institui-se um salário incentivo, sendo essa talvez a primeira vez que surge a ideia de remuneração humana do trabalho.

Nesse mesmo período o médico italiano Bernardino Ramazzini escreveu sobre doenças e lesões relacionadas ao trabalho. Seus estudos foram publicados por volta de $1700 \mathrm{em}$ um livro denominado "De Morbis Artificum Diatriba" (Doenças ocupacionais). Porém, foi censurado ao visitar seus pacientes nos locais de trabalho a fim de identificar as causas de suas doenças. Ramazzini é considerado um dos primeiros estudiosos das causas das doenças ocupacionais.

No fim do século XVII já se observavam estudos referentes à substituição dos seres humanos por máquinas nos postos de trabalho, principalmente em construções, para poupar a saúde e integridade física dos trabalhadores. É exatamente nessa ocasião que se incluem os estudos de Bernard Forest de Bélidor, com planejamento do trabalho e das interfaces ergonômicas na organização do trabalho.

\section{Biografia}

Bernard Forest de Bélidor nasceu na Catalunha (Espanha), segundo pesquisadores em 1697 ou 1698, filho de Jean-Baptiste Forest de Bélidor, um oficial militar francês que estava em serviço na Espanha, e Marie Hébert. Cinco meses após seu nascimento seu pai e sua mãe faleceram, quando, então, passou aos cuidados da família da viúva de seu padrinho, outro oficial militar, chamado Fossiébourg.

Sua vida foi dividida entre o militarismo e a ciência. O gosto pela matemática assegurou-lhe uma participação nas pesquisas de Jacques Cassini e Philippe de La Hire. O seu talento chamou a atenção do duque de Orléans, que o indicou para um cargo de professor de matemática na Escola de Artilharia de La Fère. Nesse cargo, escreveu diversos manuais técnicos durante as décadas de 1720 e 1730 . Dedicou-se às ciências e à engenharia civil e tornou-se especialista em hidráulica e matemática, realizando projetos de rodas d'água, 
que recebiam a água por canaletas, e que ainda hoje podem ser encontradas em algumas áreas rurais (Gillispie, 1970).

Entre suas publicações estão: Nouveau Cours de mathematiques, que compreende suas aulas de matemática aplicada à engenharia militar na escola La Fère (1725; ampliada, revisada e editada por Mauduit, 1759); La science des ingenieurs dans la conduite des travaux de fortification et d'architecture civile (6 vol., 1729-1734; $2^{\mathrm{a}}$ ed., Paris, 1749, e Hague, 1753; nova edição ilustrada e comentada por Navier, Paris, 1837). Le bombardier françois ou Nouvelle methode de jeter les bombes axec precision (1731; Amsterdã, 1734); Traite des fortifications (2 vol., 1735); e Architecture hydraulique (4 vol., ilustrado, 1737-1753), que permanece com grande relevância.

Publicou também diversos manuais, nos quais os construtores podiam se basear para desenvolver suas edificações, incluindo análises e planos de trabalho para dividir e direcionar o trabalho. Suas teorias foram aceitas por toda a Europa continental, praticamente sem questionamentos, até o final do século XVIII.

Para a área militar, realizou alguns experimentos sobre a carga de pólvora de canhões, descobrindo que poderiam ser utilizadas apenas oito libras de pólvora, ao invés das doze utilizadas até então. Revelou secretamente suas descobertas ao cardeal Fleuri, então primeiro-ministro. Fleuri, no entanto, acabou por comunicar ao mestre de artilharia, príncipe de Dombes (Dombes é uma região no sudeste da França).

O príncipe de Dombes ficou descontente ao descobrir que o achado não fora comunicado diretamente a ele, já que Bélidor era um matemático que trabalhava sob suas ordens, e o obrigou a deixar a escola de La Fère. Assim, Bélidor ficou desprovido de sustento, até que o príncipe de Conti (Conti se refere a um título aristocrático francês), que conhecia o seu mérito, o levou à Itália (Davenport, 1831).

Após um intervalo de atividades militares na Bavária (Alemanha), Itália e Bélgica, durante a Guerra de Sucessão Austríaca, Bélidor voltou à França sob a liderança do então ministro da guerra marquês de Belle-Islé. No seu retorno foi patenteado como briga- 
deiro e admitido como inspetor de artilharia, condecorado como Cavaleiro da Ordem de Saint Louis e ganhou uma residência luxuosa em Paris, onde se estabeleceu. Foi eleito um associado livre da Academia de Ciências em 1756.

Aos 62 anos, em gratidão à proteção recebida durante sua infância pelo seu padrinho, Bélidor casou-se com a filha, ou possivelmente neta, de Fossiébourg dois anos antes de seu falecimento, em Paris, no dia 8 de setembro de 1761, aos 64 anos de idade (Gillispie, 1970).

\section{Algumas contribuições para a engenharia civil e mecânica}

A compreensão do comportamento das estruturas foi um fator importantíssimo para o rápido desenvolvimento das engenharias no século XIX. A partir de meados do século XVIII, as estruturas passam de uma produção artesanal para serem determinadas por sua capacidade portante, calculada a partir de fundamentos científicos e de resultados de ensaios (Mattos, 2006).

Baseados na mecânica, e com o auxílio de resultados experimentais, Hooke (1635-1703), Bélidor (1693-1761), Bernoulli (17001782), Coulomb (1736-1806) e outros haviam estabelecido os fundamentos da estática.

Posteriormente, Navier (1735-1806) ordenou esse conhecimento, resumindo-o e complementando-o em suas preleções na "École des Ponts et Chaussées” (1821), transformando-o em um conhecimento prático, ou no que hoje se conhece por tecnologia (Mattos, 2006).

Em seus estudos sobre estática, Bélidor representou superfícies rugosas por meio de esferas idênticas. O estudo das forças de contato empregando esse modelo constituiu-se na primeira tentativa de relacionar área de contato com a força normal. Futuramente, essa tentativa permitiu que a primeira lei do atrito fosse deduzida a partir do crescimento das áreas reais de contato ou com o aumento da força aplicada (Sinatora, 2005). 
O livro La science des ingenieurs dans la conduite des travaux de fortification et d'architecture civile (1729-1734), dividido em seis volumes, tratou basicamente da construção ou destruição de fortificações, sendo constantemente atualizado e transformando-se no breviário de várias gerações de engenheiros até ao século XIX.

O primeiro volume, chamado Théorie de La Maçonnerie, lida com o projeto de muros de contenção de solo. Consiste basicamente em um tratado sobre as propriedades mecânicas do solo e sua influência na carga depositada nos muros de contenção. Poucos avanços científicos foram feitos nesse volume, sendo apresentadas tabelas de espessura e desgaste desses muros.

O segundo volume, Mécanique dês Voûtes, aborda a teoria de La Hire e é direcionado ao cálculo estrutural de forças em arcos, principalmente voltados à construção de pontes. Porém, Bélidor se afasta do questionamento acadêmico de La Hire ao determinar a massa das vassoir (pedras em forma de cunha) para obter equilíbrio estrutural (Gillispie, 1970).

Baseando-se na teoria da cunha (wedge theory) de La Hire, desenvolveu cálculos para a determinação de arcos na construção civil, incluindo a definição de quantas peças (vassoir) deveriam compor esses arcos e a sua massa, a fim de obter equilíbrio e resistência estrutural. O modelo desenvolvido por Bélidor especifica a proporcionalidade de massas de cada componente do arco, no entanto, assim como La Hire, não considera o atrito nas junções dessas peças.

O terceiro volume se diferencia por uma discussão qualitativa sobre as propriedades dos materiais de construção, incluindo pedras, tijolos, cal, areia, gesso e argamassa. Unidades de massa são apresentadas para uma variedade de materiais, incluindo metais (ferro, latão, cobre, etc.), areia e cal, tijolos e vários tipos de madeira. Porém não menciona dados quantitativos, referentes às forças, por exemplo.

O quarto volume, da mesma forma, trata de ensaios destrutivos realizados em vigas construídas por seus alunos na La Fère (cadetes do exército). Aparentemente, esses ensaios eram realizados para ilustrar seus ensinamentos e, do ponto de vista atual, não foram 
bem conduzidos. Os seus testes demonstravam os achados de Galileu Galilei sobre a proporcionalidade entre força e o quadrado da profundidade.

O quinto volume trata de questões arquitetônicas, como a ordem clássica, conicidade de colunas. O sexto e último volume trata de preparações, especificações técnicas e contratos.

Outra obra de grande impacto foi Architecture hydraulique (1737-1753), assim intitulada refletindo o contexto da época, no qual havia a proeminência de problemas envolvendo transportes, construção de embarcações, hidrovias, abastecimento de água e fontes ornamentais. Voltada para engenheiros civis envolvidos diretamente no desenvolvimento de projetos, abordou os principais tópicos construtivos do século XVIII (Encyclopedia, 2008).

Composta de quatro volumes, essa obra descreveu tudo o que era conhecido até então sobre engenharia hidráulica, um verdadeiro clássico, em que se empregou pioneiramente o cálculo para solucionar problemas técnicos (Semensato et al., 2009).

Nessa obra, a bomba d'água, introduzida no ocidente no século XVII, usada em projetos hidráulicos e pelos bombeiros, foi alvo de análise geométrica e mecânica, na qual Bélidor apresentou uma explicação geral de seu funcionamento. Com auxílio dessa análise foi possível especificar a forma ideal do palete para uma determinada circunstância (Chalmers, 1994).

A bomba d'água "espinha dorsal do dragão" era uma bomba usada na sociedade chinesa tradicional para irrigar os arrozais. A água era carregada em paletes, que eram levados em ângulo reto por um mecanismo de bicicleta. Havia certa variação no desenho dessa bomba, especialmente quanto à forma dos paletes, que variava de uma circunstância para outra, presumivelmente como resultado da experiência prática dos que a utilizavam (Chalmers, 1994).

Porém, enquanto os chineses tradicionais possuíam o conhecimento artesanal baseado na experiência prática, o tratamento de Bélidor constituía um conhecimento científico. A geometria e a teoria das máquinas que ele usou eram gerais, no sentido de que se aplicavam a qualquer situação mecânica. A resultante teórica da 
bomba da espinha dorsal do dragão usada pelos chineses poderia ser empregada para projetar bombas destinadas tanto a circunstâncias novas como as já conhecidas (Chalmers, 1994).

A codificação e a especificação de modus faciendi realizadas por Bélidor em seus diversos manuais não impediram avanços científicos e tecnológicos. Suas obras foram constantemente reimpressas por cerca de um século, e influenciaram gerações de engenheiros, como Lazare Carnot, Coulomb e Meusnier, seguidos por Coriolis, Navier, e Poncelet, todos sob a égide da então conhecida como ciência das máquinas, que futuramente se desenvolveria em engenharia mecânica (Gillispie, 1970).

\section{Algumas contribuições para a ergonomia}

Segundo Laville (1976), Bélidor tentou medir a capacidade de trabalho físico nos locais de trabalho dos operários no século XVIII, indicando que uma carga muito alta de trabalho leva a uma predisposição a doenças, e uma melhor organização das tarefas melhora o rendimento.

Os estudos de Bélidor foram voltados para as construções de pontes e muralhas, visando aumentar a eficiência dessas edificações, que na época se tornavam grandiosas e necessitavam de uma construção mais veloz. Esses estudos eram realizados no local de trabalho e analisavam como o trabalhador se comportava especificamente no que tangia ao carregamento de cargas por longo período, relacionando esforço muscular e postura, que posteriormente foram considerados irregulares.

Em muitos de seus desenhos, Bélidor demonstrava como o ser humano interagia com as máquinas e de que forma o trabalho era realizado com esses instrumentos que facilitavam o carregamento de peso, entre outros esforços que anteriormente eram realizados pelo próprio trabalhador. Verificam-se em suas anotações várias ilustrações: elevadores de cargas, balsas utilizadas em bate-estacas de pontes, entre outras, muitas utilizando roldanas. 


\section{Influência de Bélidor na formação das engenharias no Brasil}

A obra Nouveau cours de mathematiques, que contém álgebra, aritmética, geometrias plana e sólida, trigonometria e geometria prática, foi muito apreciada no início da formação dos cursos de engenharias no Brasil. Além disso, muitos de seus estudos foram utilizados em diferentes obras de fortificação do período colonial do Brasil (Cavalcanti, 2004).

A engenharia surge no Brasil no século XVIII com o Real Corpo de Engenheiros no Rio de Janeiro, quando uma grande quantidade de notáveis militares portugueses veio para o Brasil. Entre esses se destaca o então sargento-mor Alpoim, designado para administrar o ensino de engenharia militar no Rio de Janeiro (Exército Brasileiro, 2010).

Esse curso foi conduzido por meio da "Aula de Artilharia", um curso de cinco anos, que no ano de 1774 passou a abranger o ensino de Arquitetura Militar, adotando como base o livro de Bélidor La science des ingénieurs dans la conduite des travaux des fortifications et des bâtiments civils (1729-1734). Daí surge a primeira escola de engenharia das Américas e terceira do mundo, em 1792 (Marocci, 2007).

Com esses acontecimentos, a influência corrente de Bélidor na Europa se instaura também no Brasil, trazida por militares portugueses e implantada nos primórdios da formação acadêmica e militar em engenharia no Brasil.

\section{Discussão e considerações finais}

A análise da tarefa, um dos focos de concentração da atual ergonomia, é uma atividade muito analisada por diversos estudiosos ao longo da história humana. Há menção de estudos que remontam à Antiguidade, quando filósofos gregos buscavam maneiras mais eficientes de produzir seus artefatos. 
Embora os registros sejam escassos, esses estudos continuaram e se intensificaram com a aproximação da Primeira Revolução Industrial (meados do século XVII), quando o ritmo e as dimensões do trabalho começaram a exigir o desenvolvimento de máquinas e dispositivos para acelerar os processos das grandes construções que eram projetadas.

Assim surgiram as contribuições dos engenheiros para auxiliar tanto nas informações estruturais como na melhor maneira de se executar trabalhos específicos que demandariam esforço e utilização de cargas excessivas, que provavelmente influenciariam na qualidade do trabalho e na melhor maneira de se executar um movimento utilizando-se do menor esforço possível.

Destaca-se a contribuição de Bernard Forest de Bélidor, engenheiro civil e militar do século XVIII, cujas publicações foram referência em toda a Europa, contendo desde tabelas e cálculos estruturais até princípios de organização do trabalho, que nortearam o projeto e execução de construções durante todo o século.

Bélidor teve sua vida marcada por contribuições militares e períodos de docência nas áreas da engenharia civil e mecânica e seus ensinamentos são utilizados até os dias atuais, contribuindo assim em estudos técnicos e ergonômicos com preceitos de melhoria do trabalho.

Suas publicações se fixaram na área da engenharia civil e arquitetura aplicada às estruturas militares, especificamente em construções de fortificações e de pontes, no intuito de definir um ritmo mais rápido para essas construções. Bélidor desenvolveu máquinas que facilitavam o carregamento de peso, balsas com bate-estacas nos rios, estudos de contenção de barragens, entre outros.

Destacam-se outras contribuições no campo de estudo da arquitetura hidráulica, como a bomba d'água utilizada pelos chineses e reestudada por Bélidor e a roda d'água utilizada até hoje em cachoeiras e moinhos, estas duas utilizadas também em fortificações militares.

No Brasil, a influência de Bélidor ocorreu nas obras de fortificações e também com o surgimento das primeiras escolas de enge- 
nharia, nas quais vários de seus conceitos foram implantados nas disciplinas dos cursos de engenharia e arquitetura.

Entre esses estudos, também se verifica a preocupação com o trabalhador no intuito de não sobrecarregá-lo ou prejudicar sua saúde no posto de trabalho. Assim, um operário sem doenças ocupacionais poderia ser mais eficiente nas construções. Por esses estudos Bernard Forest de Bélidor é considerado um dos precursores da ergonomia, e, posteriormente, seus estudos foram utilizados e desenvolvidos por outros estudiosos.

\section{Referências bibliográficas}

CAVALCANTI, N. O. O Rio de Janeiro setecentista: a vida e a construção da cidade da invasão francesa até a chegada da corte. Rio de Janeiro: Editora Jorge Zarah, 2004.

CHALMERS, A. A fabricação da ciência. São Paulo: Editora Unesp: 1994. DAVENPORT, R. A. A dictionary of biography. Londres: Thomas Tegg, 1831.

ENCYCLOPEDIA. Bélidor, Bernard Forest de. In: Complete dictionary of scientific biography, 2008.

EXÉRCITO BRASILEIRO. Histórico resumido da CRO/1. Disponível em http://www.cro1.eb.mil.br/pagconh.htm. Acessado em 18/3/2010.

GILLISPIE, A. Dictionary of scientific biography. Nova York: vol. 1, p.581, 1970.

LAVILLE. A ergonomia. São Paulo: EPU, 1977.

MAROCCI, Gina Veiga Pinheiro. CEFET-BA. Disponível em http:// www.sbhe.org.br/novo/congressos/cbhe4/individuais-coautorais/ eixo02/

Gina\%20Veiga\%20Pinheiro\%20Marocci\%20-\%20Texto.pdf. Acessado em 18/4/2010.

MATTOS, P. de. Fundamentos da mecânica dos sólidos e das estruturas. São Paulo: LMC-USP, 2006.

SEMENSATO, C. B.; DE PAULA, A. J. F.; SILVA, J. C. P. da; CARNEIRO, L. do P.; PASCHOARELLI, L. C. Engenheiros precursores da ergonomia e suas contribuições. In: Anais do $5^{\circ}$ CIPED Congresso Internacional de Pesquisa em Design, 2009.

SINATORA, A. Tribologia: um resgate histórico e o estado da arte. São Paulo, 2005. 


\title{
3 \\ PATISSIER: \\ FRAGMENTOS DE UMA CONTRIBUIÇÃO À ERGONOMIA
}

\author{
Ana Cláudia Scarpim \\ Cláudio Vidrih Ferreira \\ José Carlos Plácido da Silva \\ Luis Carlos Paschoarelli
}

\section{Introdução}

Ao se analisar a origem do homem, pode-se afirmar que é praticamente certo que o trabalho surge de suas ações ativas sobre a natureza. Para se alimentar, o homem primitivo foi obrigado a coletar frutos e vegetais, posteriormente abater animais e, consequentemente, desenvolver atividades agrícolas, as quais foram imprescindíveis à sua sobrevivência e ao seu desenvolvimento evolutivo, cognitivo e social.

O conceito trabalho foi contemplado nas Sagradas Escrituras, sendo que a Bíblia o apresenta como uma maldição ligada à fadiga, indicando-o como um sacrifício. Nesse sentido, a primeira definição conhecida de trabalho está gravada no Gênesis 3:17b, 19 "Disse, pois, o Senhor Deus ao homem... maldita seja a terra por tua causa; tirarás dela com trabalhos penosos o teu sustento todos os dias da tua vida. Comerás o teu pão com o suor do teu rosto, até que voltes à terra de que fostes tirado; porque és pó, e em pó te hás de tornar" (Bíblia, 1997).

O termo trabalho, que advém do latim tripaliu, então caracterizado como um instrumento de tortura utilizado durante a idade média, representando uma associação com o sofrimento humano. 
De qualquer maneira, as necessidades de sobrevivência levaram o homem primitivo a evoluir e descobrir que uma pedra poderia ser afiada até ficar pontiaguda e transformar-se numa lança, machado ou outro instrumento que traria maior eficiência às suas atividades. Possivelmente, e inconscientemente, o homem pré-histórico começava a aplicar a ergonomia.

Também, de acordo com Rivas (2007), um dos antecedentes mais antigos do pensamento ergonômico se encontra no Código de Hamurabi, Rei da Babilônia (1700 a.C.), quando introduziu uma série de medidas de configuração laboral, entre as quais se mencionam: planificação e controle da produção baseada na contagem da mão de obra, sequência de tarefas e tempo necessário para sua execução, associado também a um salário mínimo.

As atividades laborais trazem consequências e, portanto, as doenças passaram a afetar o homem desde os primórdios da humanidade. Conforme Silva (2006), na Antiguidade já eram conhecidos os problemas na coluna nos carregadores de pedra, as cólicas pelo chumbo nos mineiros e a intoxicação pelo mercúrio.

Nesse contexto, os estudos dos médicos e higienistas ganharam espaço e contribuíram para minimizar as doenças provenientes do trabalho. Entre os inúmeros abnegados e idealistas que contribuíram para melhorar a qualidade de vida dos homens do passado, destaca-se o médico francês Philibert Patissier.

\section{Breve histórico da medicina antiga}

Desde civilizações antigas, o homem sempre buscou melhorar as ferramentas, os instrumentos e os utensílios que usa na sua vida cotidiana. Existem exemplos de empunhaduras de foices, datadas de muitos séculos atrás, que demonstram a preocupação em adequar a forma da pega às características da mão humana, de modo a propiciar mais conforto durante sua utilização (Moraes e Montalvão, 2000).

Nesse cenário, de acordo com Martins (2002), o início da história da ergonomia remonta a criação das primeiras ferramentas, 
quando o homem pré-histórico provavelmente escolheu uma ferramenta que melhor se adaptasse à forma e ao movimento de sua mão.

Embora os homens na Antiguidade procurassem evitar, os primeiros acidentes de trabalho ocorreram com a fabricação das primeiras ferramentas. Tanto que a patologia profissional (ocupacional) foi já descrita na Bíblia e nos tempos antigos.

Um papiro de 2500 a.C. contém a descrição no Egito antigo de acidente com diagnóstico de lombalgia aguda resultante de um trabalhador envolvido na construção de uma pirâmide.

Também, de acordo com a revista Travail (1999), há mais de 2.000 anos, os trabalhadores que construíram as pirâmides do Egito já sofriam de silicose. O primeiro caso documentado de câncer ocupacional remonta a 1775 , quando os cientistas descobriram que a fuligem foi a causa do câncer escrotal das crianças em Londres.

Por volta de 450 a.C., Hipócrates, considerado o pai da medicina, já havia observado que a asma era a patologia mais comum em certos profissionais, como alfaiates e pescadores. Há também referências a doenças profissionais em Plínio, o Velho, e Julius Pollux.

As correlações entre as atividades laborais e as doenças permaneceram ignoradas por um período expressivo, tendo suas primeiras publicações ocorridas a partir do século XVI. A seguir, extraído do Scribd (2010), são indicadas algumas contribuições históricas que se estendem da Antiguidade até o século XVIII:

- Hipócrates (460-377 a.C.): médico grego, considerado o pai da medicina, em sua obra intitulada "Ares, Águas e Lugares", descreve a patologia do chumbo ligada à extração mineira.

- Platão (427-347 a.C.): relata as deformidades ósseas e musculares dos artesãos.

- Plínio (23 a.C-79 d.C.): naturalista romano, descreve o uso de máscaras de borracha, panos ou membranas para atenuar a inalação de poeiras (por iniciativa dos escravos $-1^{\circ} \mathrm{EPI}$ ).

- Lucrécio (99-55 a.C.): poeta latino, descreve os horríveis e penosos trabalhos nas minas de Siracusa, cujas tarefas diárias 
prolongavam-se por 10 horas, em galerias de 1 metro de altura por 0,60 metro de largura.

- Georg Bauer ou Georgius Agrícola (1494-1555): conhecido como o pai da mineralogia, em seu livro De re metallica discute os aspectos relacionados à extração de minerais. Acidentes do trabalho - Asma dos mineiros.

- Paracelso (1494-1541): médico, alquimista, físico e astrólogo, em seu livro aborda as relações entre trabalho e doença, com destaque a intoxicação pelo mercúrio.

\section{Contribuições de Ramazzini e outros}

Por volta de 1700, Bernardino Ramazzini (1633-1714), médico italiano, considerado o pai da medicina do trabalho, publicou o livro De morbis artificum diatriba (doenças do trabalho), no qual descreve uma série de doenças relacionadas a cerca de cem profissões diferentes, bem como os riscos específicos decorrentes de cada uma delas, tornando-se um marco referencial no início de um período de maior aprofundamento em relação às questões ligadas às doenças ocupacionais.

Num quadro simplista, no século XVII, Ramazzini se interessa pelas consequências das condições de trabalho e descreve, através de monografias, as primeiras doenças profissionais: problemas oculares de pessoas que fabricam pequenos objetos, custos humanos posturais dos alfaiates, danos à coluna vertebral relacionados à movimentação de cargas pesadas, surdez dos caldeireiros de Veneza (Martins, 2002).

Ramazzini sofreu grande discriminação de outros médicos por se dedicar, rotineiramente, a visitas aos locais de trabalho de seus pacientes a fim de identificar as causas de seus problemas e poder contribuir com o bem-estar desses operários.

Após Ramazzini, de acordo com Vidal (2010), aparecem algumas referências como as alusões às deformações posturais apontadas por Plaute. Nesse mesmo período, anotam-se trabalhos no 
campo da toxicologia e da patologia do trabalho, abordando particularmente riscos físicos como os impactos da temperatura e da umidade (Villeneuve, Coulomb e Lavoisier, século XVIII) e riscos ergonômicos como a adoção de posturas inadequadas (Villeneuve).

Para Menezes \& Menezes (2008), existem também registros de estudos de biomecânica e antropometria (Leonardo da Vinci), trabalhos de higiene industrial, basicamente sobre ventilação e iluminação dos locais (Désargulires, Hales e Camus, século XVI; D'Arret, século XIX), e de medicina do trabalho, tanto num âmbito específico de afecções profissionais (Ramazzini e Tissot, século XVIII) como na epidemiologia (Villermé e Patissier, século XIX).

De acordo com Martins (2002), no século XVIII, Tissot se interessou pela climatização dos locais de trabalho e propôs a criação de serviços nos hospitais para atender artesãos doentes.

Este último século, ainda consoante Vidal (2010), é também a origem da higiene do trabalho, destacando-se D'Arret, nas regras de higiene nas fábricas e Patissier, que é considerado o mentor do movimento para criação da inspeção do trabalho na França.

\section{Pequena biografia de Philibert Patissier}

Biograficamente, o conteúdo disponível a respeito de Philibert Patissier é muito escasso. Tanto nas bibliotecas, nas diversas plataformas, quanto na internet, nos vários sites de busca, a quantidade de informações é muito pequena e, às vezes, conflitante, gerando dúvidas quanto ao informado.

Em alguns sítios, há indicativo de que Patissier nasceu em 1781, enquanto em outros é destacado o ano de 1791. Surpreendentemente, consta que Philibert casou-se com Claudine Recorbet em 11 de janeiro de 1764, de cuja união nasceu Claudine Patissier, em 1767 , conflitando com o ano de nascimento do próprio pai que teria ocorrido no final do século XVIII.

No jornal francês Un Móis à Mâcon, nº 63, de maio de 2007, com matéria intitulada Le chateau d'Aisne (O castelo de Aisne) é 
destacada a história do referido castelo. A seguir, apresenta-se uma síntese da matéria publicada nesse jornal:

Ao longo dos séculos, existem três nomes diferentes para esse lugar: Aine, Ennes e Aisne, que é localizado na cidade de Aze. No início do século XVI, Aisne foi um pequeno pátio com cinco casas. Gilbert Regnaud, juiz Cluny, tornou-se proprietário em 1561. Com sua morte, seu filho Jacques herdou a propriedade, mas, em seguida, vendeu o imóvel, em 1600, a Vincent Bernard, capitão Mâcon.

No século XVIII, a propriedade passou para as mãos de Philibert Patissier, que construiu um castelo novo no lugar do antigo, entalhando na fachada da propriedade o brasão da família.

Conta ainda a matéria histórica que na cidade de Mâcon, em 27 de julho de 1789, um bando de ladrões saqueou o castelo. Durante a Revolução, o castelo, em mau estado, tornou-se uma simples loja de caça. Proprietário, por herança, o conde Victor Murard St. Romain restaurou o castelo em torno de 1858 usando "pedreiros de Piemonte".

No início do século XX, a propriedade foi vendida à família Testot-Ferry, então a José e Chervet Louis Vougnon. O último proprietário privado, Sokolnikoff Mendel, adquiriu o imóvel em 1939. Atualmente, o castelo restaurado é dirigido pelo "The Parc des Expositions”, do Tinailler, que o aluga para congressos, recepções, eventos, etc.

\section{Contribuições de Patissier}

Já no século XIX, Patissier se volta para o saturnismo e a silicose, e insiste na proteção individual. Preconiza o uso de bexigas animais para proteção respiratória e de óculos para proteção contra corpos estranhos. Ele recomenda aos ourives levantar a cabeça de vez em quando e olhar para o infinito como modo de evitar a fadiga visual. Também preconiza proteção nos moinhos e concebe máquinas para diminuir o esforço físico, como as máquinas de lavar. 
Nesse período, Patissier realiza as primeiras estatísticas sobre mortalidade e morbidade da população operária. Após o trabalho de Ramazzini, Patissier (1822) publicou um novo tratado sobre as doenças dos artesãos e aquelas provenientes de várias outras profissões.

Conforme Boisselier (2004), esse livro se baseia e complementa o Tratado de Ramazzini, aplicado ao estudo de tais distúrbios, relativo a 213 ocupações, indicando as precauções (prevenção e tratamento) a serem tomadas nas fábricas pelos fabricantes, pelos chefes de oficinas e por todas as pessoas envolvidas em operações insalubres. Patissier foi além de Ramazzini, interessando-se não só pelas doenças que ocorriam naquelas ocupações estudadas, mas também em casos de acidentes do trabalho, indicando como podiam ocorrer e como evitá-los. Desse modo:

- ele fala sobre as lesões sofridas por crianças, que ficavam expostas a quedas frequentes, sendo vítimas de sua própria falta de cuidados, e indicava procedimentos de trabalhos que poderiam evitar essas lesões;

- enfatiza medidas para evitar acidentes, incluindo explosões de gás, e destaca várias precauções que deviam ser tomadas, principalmente o retorno às minas de carvão, após os feriados e domingos;

- sugere medidas de proteção nos trabalhos de fábrica, com recomendação de maneiras para prevenir os efeitos dos trabalhos que envolviam metais, e minerais com exalação de vapores.

Patissier também ressaltou ser possível orientar as crianças para uma profissão específica, em função da sua constituição física, seu temperamento e disposições legais (Boisselier, 2004).

Segundo Boisselier (2004), o professor Salmont, fundador da cadeira de segurança do trabalho, no Conservatoire National des Arts et Métiers, declarou durante o seu jubileu em 19 de maio de 1951: "A publicação do presente Tratado no início do século XIX fez de Patissier, também médico, assim como Ramazzini, o promotor de 
ideias”, faria surgir na França um movimento a favor da segurança do trabalhador cujo âmbito se estenderia para o resto do mundo.

Em 1776, consoante Boisselier (2004), Antoine François de Fourcroy havia publicado a tradução francesa da obra de Ramazzini, acompanhada de notas e de um prefácio afirmando conhecer os problemas abordados pelo médico italiano quase um século antes. Ele destacou especialmente em seu prefácio as consequências nefastas da evolução técnico-científica descontrolada.

O Tratado de Patissier foi difundido na França, e suas ideias foram amplamente adotadas. Sua preocupação com a prevenção, especialmente no que diz respeito aos acidentes com máquinas, foi amplamente difundida, sendo compartilhada pelas mais variadas empresas da França.

Enriquecendo sua valiosa contribuição à medicina do trabalho, Patissier, em 1833, publicou em Paris outra obra, intitulada " $M a$ nuel des eaux minerales de la France".

Vale destacar que Philibert Patissier era doutor em medicina pela Faculdade de Paris, médico-adjunto do $3^{\circ}$ Dispensário da Caridade, membro do Atheneu de Medicina de Paris e membro da Sociedade de Ciências, Artes e Belas Artes de Mâcon.

\section{Discussão e considerações finais}

Desde a Antiguidade, os homens sofrem com doenças relativas ao trabalho, também chamadas de doenças ocupacionais.

Embora a ergonomia tenha o ano de 1949 como marco histórico, é inegável que ela já era praticada e empregada desde os primórdios da humanidade.

Homens abnegados e despojados de promoção pessoal se dedicaram a estudar as doenças ocupacionais na tentativa de minimizar o sofrimento das pessoas e de contribuir para um ambiente de trabalho mais humano.

Entre os inúmeros precursores da ergonomia, Philibert Patissier foi um daqueles que marcou época e legou para a humanidade 
significativas contribuições para o desenvolvimento da medicina e saúde pública, a serviço do bem-estar das pessoas.

\section{Referências bibliográficas}

BÍBLIA Português. Bíblia sagrada. Trad.: Centro Bíblico Católico. 113. Ed. rev. São Paulo: Ave Maria, 1997, 1.638p.

BOISSELIER, J. Naissance et évolution de l'idée de prévention dês risques professionnels - petit histoire de la réglementation em hygiène, em sécurité, et em conditions de travail. $2^{a}$ ed., Paris, v.1,175p. Institut national de recherche et de sécurité. 2004. ISBN 2-7389-1228-1. Disponível em http://books.google.com. Acessado em 3/3/2010.

MARTINS, M. C. Ergonomia e LER/DORT. 2002. Disponível em http:// www.ergonet.com.br/ download/ergonomia-lombalgias.pdf. Acessado em 3/3/2010.

MENEZES, W. J. \& MENEZES, F. H. O. Ergonomia: conceitos introdutórios e noções de sistema informacional. 2008, 83p. www.fortium.com. $\mathrm{br} /$ faculdadefortium.com.br/wladimir.../4623.doc

MERINO, E. Ergonomia. Apostila. Universidade Federal de Santa Catarina-UFSC. 2004. 47p.

MORAES, A.; MONT'ALVÃO, C. Ergonomia: conceitos e aplicações. Rio de Janeiro, 2AB, 2000, $2^{a}$ ed., 136p. ISBN 85-86695-05-X.

RIVAS, R. R. Ergonomía. Em el diseño y la producción industrial. $1^{a}$ ed. Buenos Aires: Nobuko, 2007, 540p. ISBN 978-987-584-089-8.

SILVA, C. A. D. Aplicação prática da Norma Regulamentadora NR 17 Ergonomia. Apostila, 2006, 76p.

SCRIBD: www.scribd.com/doc/486075/ergonomia-qualidade-e-produtividade-texto1. Acessado em 5/3/2010.

TRAVAIL. Des fuites radioactives au décalage horaire: la liste des risques professionnels s'allonge. N. 28, février 1999. Editions archivées. Encyclopédie de sécurité et de santé au travail. Disponível em http:// search.ilo.org/public/french/bureau/inf/magazine/28/encyclop.htm. Acessado em 7/3/ 2010.

VIDAL, M. C. Introdução à ergonomia. Fundação Coppetec - Grupo de Ergonomia e Novas Tecnologias Parceria: Crea (RJ). Disponível na internet, 2010, 35p. 



\title{
4 \\ DA ORGANIZAÇÃO CIENTÍFICA \\ À ERGONOMIA: \\ A CONTRIBUIÇÃO DE \\ FREDERICK WinsLOW TAYLOR
}

\author{
Bruno Montanari Razza \\ Cristina do Carmo Lucio \\ José Carlos Plácido da Silva \\ Luis Carlos Paschoarelli
}

\section{Introdução}

As primeiras medidas e observações sistemáticas do trabalho foram desenvolvidas por engenheiros, organizadores do trabalho, pesquisadores e médicos, sendo que os engenheiros e organizadores o fazem numa perspectiva de aperfeiçoamento do rendimento do homem no trabalho (Laville, 1977).

Entre os organizadores do trabalho, estão Frederick Winslow Taylor e seus precursores, que analisaram o trabalho, tendo em vista definir as melhores condições de rendimento, aprimorando o desempenho do homem e baseando-se no modelo análogo ao funcionamento da máquina (Laville, 1977).

No fim do século XIX já se verificava uma grande competitividade, com rápido crescimento de corporações e início de organizações industriais que monopolizavam o mercado. Esse fato tornava cada vez mais difícil a sobrevivência no mercado de indústrias que apresentavam baixa produtividade (Cooper; Taylor, 2000).

Nesse contexto, de uma indústria desorganizada e pouco eficiente, sem controle ou conhecimento aprofundado das tarefas realizadas pelos seus trabalhadores, Taylor desenvolveu a sua teoria e 
introduziu o conceito da Administração Científica, revolucionando o sistema produtivo do começo do século XX, formando a base sobre a qual se desenvolveu a atual Teoria Geral da Administração (Coelho; Gonzaga, 2009).

Este artigo tem por objetivo apresentar a importância e contribuição dessa teoria e principal obra de Taylor para o processo produtivo industrial de sua época, discutindo a sua influência sob o ponto de vista da ergonomia. Para isso, este trabalho inicia-se pela apresentação de uma breve biografia, o contexto socioeconômico contemporâneo a ele, uma apresentação da sua obra e uma análise crítica de diversos pontos de vista de suas consequências para as relações entre o homem e o trabalho.

\section{Breve biografia de Frederick Winslow Taylor}

Filho de Franklin Taylor e de Emily Annete Winslow, Frederick Winslow Taylor nasceu em 20 de março de 1856, em Germantown, Pensilvânia, EUA. Seu pai era um influente advogado formado em Princeton e sua mãe uma feminista e abolicionista. A família Taylor era um importante membro dos Quakers - fundação de cunho religioso e tradição protestante criada em 1652 pelo inglês George Fox com objetivos pacifistas e abolicionistas, gozando de certa influência na sociedade local (Coelho; Gonzaga, 2009. Rago; Moreira, 1984).

Desde cedo, Frederick foi educado por sua mãe, estudou na França e na Alemanha e viajou pela Europa. Em 1872, ele ingressa na Academia Phillips Exeter em New Hampshire com o intuito de se preparar para a universidade. Ao se formar, é aceito no curso de Direito em Harvard, porém decide seguir outra carreira (Coelho; Gonzaga, 2009).

Taylor começa a trabalhar como aprendiz em uma indústria, a Enterprise Hydraulic Works, onde permanece até 1878, quando vai para a Midvale Steel Works, especializada na construção de máquinas. Taylor começou como operário, mas logo passou para escritu- 
rário, maquinista, contramestre (gerente) e finalmente engenheirochefe (Coelho; Gonzaga, 2009. Rago; Moreira, 1984).

Aos 27 anos, em 1883, Taylor se forma em Engenharia Mecânica no Instituto de Tecnologia de New Jersey. Foi nessa época que ele desenvolveu uma série de dispositivos para o corte de metais. No ano seguinte, em 3 de maio de 1884, casa-se com Louise M. Spooner (Coelho; Gonzaga, 2009).

De 1890 a 1893, Taylor trabalha como gerente-geral e engenheiro-consultor na Manufacturing Investment Company, onde teve a oportunidade de que precisava para testar suas teorias. Em 1983, Taylor deixa a companhia para abrir seu próprio negócio como consultor independente. Em 1898, ingressa na Bethlehem Steel, onde, junto com Maunsel White e uma equipe de assistentes, desenvolve o "high speed steel", HSS ou aço rápido, um material usado na fabricação de ferramentas de corte largamente utilizado até hoje. Nesse mesmo ano, Taylor reestrutura uma tarefa de carregar lingote modificando a seleção, treinamento e turnos de trabalho e descanso para que o trabalhador pudesse movimentar 47,5 toneladas por dia - antes a média de carga transportada era de 12,5 toneladas. Taylor também projetou uma série de pás para transportar diferentes tipos de materiais (ADAMS, 1989 apud Meister, 1999), cujo estudo ele atribuiu o título de "A Ciência da Pá" ou "The Science of Shoveling".

Nesse estudo, Taylor determinou que o peso ideal que um trabalhador deveria levantar sobre uma pá era de cerca de 10 quilos. Considerando que há uma ampla faixa de densidade de materiais, a pá deveria ser dimensionada de modo que mantivesse esse peso da substância a ser carregada. Para tanto, foram desenvolvidos alguns modelos, desde uma de menor dimensão para minérios a uma de maior dimensão para cinzas. Essas pás deveriam ser dimensionadas de forma que o trabalhador pudesse manipulá-las e que cada um utilizasse a sua própria. A partir de então, a empresa Bethlehem Steel providenciou aos trabalhadores as pás ideais, e o resultado foi o aumento de três a quatro vezes a produtividade dos trabalhadores, que foram recompensados com aumentos salariais (Taylor, 1970). 
Em 1901, já bastante conhecido, Taylor deixa a Bethlehem Steel devido a desavenças com outros gerentes (Meister, 1999. Coelho; Gonzaga, 2009).

No mesmo ano, Frederick e sua esposa decidem adotar três filhos: Kempton, Robert e Elizabeth. Em 1903, publica seu primeiro livro sobre o que mais tarde chamaríamos de administração científica, "Shop Management" (Direção de Oficinas), no qual trata pela primeira vez de suas ideias sobre a racionalização do trabalho (Coelho; Gonzaga, 2009. Rago; Moreira, 1984).

Em 1906, publica "The Art of Cutting Metals" (A Arte de Cortar Metais), é eleito presidente da Associação Americana dos Engenheiros Mecânicos e recebe o título honorário de Doutor em Ciência pela Universidade da Pensilvânia (Coelho; Gonzaga, 2009).

Somente em 1911 é que Taylor publica sua obra mais importante, revelando de vez os princípios da administração científica que se tornariam a base da Teoria Geral da Administração. Em 1915, contrai uma pneumonia e morre no dia 21 de maio (Coelho; Gonzaga, 2009).

\section{Contexto socioeconômico precedente ao taylorismo}

A administração científica surgiu como uma reação aos precários métodos de organização vigentes no processo produtivo industrial das indústrias americanas do fim do século XIX e início do XX (Kanigel, 1997 apud Cooper; Taylor, 2000). Os donos de fábricas forneciam apenas a estrutura física para a produção (local, energia e matéria-prima, ferramentas, maquinário, etc.) e contratavam feitores para organizar o trabalho. Esses feitores agiam como subempreiteiros e tinham o dever de selecionar os trabalhadores, organizar as tarefas básicas da indústria e gerenciar o chão de fábrica da melhor forma possível. A administração ficava preocupada apenas com o produto final, preços, prazo de entrega e lucro, tendo apenas uma noção geral da produtividade e tratando o trabalho com descaso (Bridger, 2009). 
Nas indústrias, os salários eram baixos, as condições de trabalho muito ruins e alguns incentivos poderiam ser oferecidos aos trabalhadores, em geral na forma de bônus salariais, para sugerir melhorias. Para se obter lucro com a produção era imprescindível para o industrial conseguir um bom profissional para organizar os trabalhadores (Bridger, 2009).

Havia na época um exército de trabalhadores sem qualificação e que apresentavam um rendimento baixo. Apesar dos baixos salários, a relação custo-rendimento desses trabalhadores era ineficiente, pois a baixa qualidade dos produtos e a morosidade da produção levavam o industrial a contratar um grande número de indivíduos.

Taylor percebeu que havia muito prejuízo com esse estilo de organização de "incentivo e iniciativa", pois ninguém era diretamente responsável pela produtividade da empresa, e o sistema era aberto à corrupção e à exploração dos trabalhadores, sendo rotineiros os casos de propinas aos supervisores e assédio sexual às trabalhadoras (Stagner, 1982 apud Bridger, 2009).

Muito pouco era feito até então para promover melhores formas de se realizar o trabalho ou sistemas de organização do processo produtivo e também não havia métodos de avaliação da eficiência dos procedimentos realizados diariamente nas indústrias.

Os trabalhadores se resignavam a realizar suas atividades e não contribuíam com sugestões de melhorias no processo produtivo, ou por total desconhecimento do que poderia ser feito ou por falta de vontade de contribuir com mudanças que poderiam aumentar os lucros da empresa, mas não se converteriam em benefícios ou melhores condições de trabalho. A administração da empresa, por desconhecer a forma como as tarefas básicas eram desempenhadas, tendo apenas uma visão geral do todo, era ineficiente para reconhecer falhas do processo produtivo e conseguir aumentar a produtividade (Bridger, 2009). Assim como o próprio Taylor disse: "o remédio para essa ineficiência reside em uma organização sistemática, ao invés da procura por algum funcionário extraordinário" (Taylor, 1970, p.27). 


\section{Princípios da administração científica}

A administração científica, preconizada por Taylor em sua principal obra (Taylor, 1970), "Princípios da Administração Científica", fundamenta-se na aplicação de métodos científicos para administrar o trabalho, tirando o poder de controle do trabalhador sobre suas ações e escolhas e transferindo-o para o setor administrativo.

As teorias de Taylor fundamentam-se sobre algumas premissas, sendo uma delas a de que existe um meio mais rápido e eficiente para realizar cada tarefa, em que a eficiência seria máxima. Para tanto, ele analisou sistemática e obstinadamente as tarefas na indústria, atentando aos movimentos e o tempo necessário para sua realização, e fragmentou-as até a sua maior simplicidade. Segundo o autor, toda e qualquer tarefa, por menor que seja, é relevante e necessita ser estudada para que se projete um melhor método para sua realização.

O trabalhador passava então a realizar tarefas específicas com controle rigoroso do tempo. O treinamento era importante, pois com instruções sistemáticas e adequadas a cada função seria possível fazer o funcionário produzir mais e com maior qualidade. Nesse sistema, deve haver um forte controle para verificar se o trabalho está sendo executado da maneira adequada, na sequência e no tempo predeterminado para não haver desperdício operacional.

Outra premissa do taylorismo é a do homem econômico, que afirma que o único fator motivador para o trabalhador realizar o seu trabalho de maneira mais dedicada é vinculando o seu pagamento à sua produtividade, sendo estabelecidas metas a serem cumpridas. A visão de Taylor era de que por meio de pagamentos o trabalhador se sentiria estimulado a trabalhar mais, cooperando com a empresa para a obtenção de lucros, o que reverteria para o bem de todos. $\mathrm{O}$ trabalhador ideal era aquele que executava as tarefas da maneira planejada pela administração, sem questionar e da maneira mais eficiente possível.

Os quatro princípios da administração científica são: 
1. Princípio de planejamento: consistia na substituição de métodos empíricos e improvisados por procedimentos científicos, com métodos avaliados. Esse planejamento rigoroso do trabalho, baseado em estudos fundamentados, inclusive estatisticamente, propiciou à administração transformar-se em uma ciência.

2. Princípio de preparo: preparar e treinar os operários para produzirem mais e melhor, de acordo com o método planejado. Incluía o treinamento do trabalhador sobre o modo ideal de realizar o trabalho e a seleção de um indivíduo ideal para cada função.

3. Princípio de controle: controlar o trabalho para se certificar de que está sendo executado de acordo com os métodos estabelecidos. O controle do tempo e dos movimentos era rigoroso na teoria de Taylor.

4. Princípio da execução: distribuir atribuições e responsabilidades para que a execução do trabalho seja disciplinada. Houve a criação do cargo de supervisor para averiguar se o método de trabalho desenvolvido estava sendo executado pelos trabalhadores.

De acordo com o próprio autor, a administração científica constituía-se na melhor forma de organização e gerenciamento, e não optar pela melhor forma seria simplesmente irracional. Por essa razão, as implementações posteriores ao taylorismo acabaram sendo chamadas de racionalização (Taylor, 1970; Björkman, 1996).

\section{Análise e crítica do taylorismo}

As ideias de Taylor proporcionaram uma revolução no processo produtivo, trazendo muitos benefícios para a sociedade da época. A administração passou a ter um sistema formal estabelecido para monitorar as práticas laborais e suas relações com a produtividade. Ficou estabelecida a coparticipação entre o capital e o trabalho, 
refletindo em menores custos, maiores salários e aumento da produtividade e competitividade das empresas. $\mathrm{O}$ custo dos produtos manufaturados ficou reduzido e, consequentemente, mais acessível, inclusive àqueles que os produziam. A repetitividade e a grande simplicidade das tarefas apresentaram algumas vantagens, como menor necessidade de trabalhadores especializados, redução de custos de treinamento, facilidade na substituição ou realocação da mão de obra, redução de ordenados, os cronogramas de produção eram mais facilmente controlados e era mais fácil prever a quantidade de produtos produzida (Bridger, 2009).

Sem dúvida, o taylorismo possibilitou o aumento considerável da produtividade dos trabalhadores, reduzindo custos de produção e consequentemente o preço das mercadorias, permitindo, sobretudo, aumentar consideravelmente os lucros e a prosperidade dos patrões, cujo benefício para o empregado, segundo Taylor, seria o aumento de seu salário habitual, sem considerar as questões humanas no trabalho (Lazzareschi, 2007).

É possível constatar pontos questionáveis sob muitos aspectos na obra de Taylor e grandes consequências sob os pontos de vista social, ideológico, econômico, ergonômico, entre outros. A despeito de suas vantagens econômicas, o taylorismo também apresentou um dilema de administração: o contínuo aumento de produtividade que implicava no contínuo aumento nos pagamentos. Devido a isso, as metas de produção eram elevadas conforme o patamar de produção era atingido. Como reação, os trabalhadores reduziam sua produtividade para evitar que níveis de produção mais altos fossem estipulados (Bridger, 2009).

Segundo Bridger (2009), há vários pontos falhos no método utilizado para o estudo do tempo e dos movimentos. Seus experimentos foram insuficientes para garantir fundamentação científica e suas afirmações não eram muito diferentes do senso comum. $\mathrm{O}$ campo de aplicação se restringia aos problemas de produção na indústria, não considerando demais aspectos da organização, como financeiro, comercial e logístico. 
Em geral, os aspectos sociais e a satisfação relacionada ao desempenho dessas tarefas eram ignorados (Björkman, 1996). Taylor presumia que todas as pessoas numa indústria têm o mesmo interesse, e que todos iriam cooperar para maximizar seus próprios lucros. "A administração científica, por outro lado, tem em seu principal fundamento a firme convicção de que os interesses dos empregados e empregadores são os mesmos" (Taylor, 1970, p.30).

Claramente, os interesses dos administradores e dos trabalhadores não eram os mesmos. A principal meta do administrador era aumentar os lucros para os acionistas, e uma das melhores formas de se fazer isso era por reduzir o custo do trabalho (Bridger, 2009). Ainda hoje essa prática pode ser observada nas empresas que terceirizam departamentos, como call centers, ou parte da produção para países emergentes, onde o custo do trabalho e a carga tributária são menores.

Segundo Arnowitz e Dykstra-Erickson (2007), Taylor projetou o layout físico da fábrica, vinculando as interações da máquina com os seres humanos em um fluxo de trabalho que garantia que um trabalhador nunca necessitaria transitar indevidamente ou desnecessariamente na fábrica. A redução das tarefas a procedimentos repetitivos e mecânicos levava a uma total alienação do trabalhador em relação ao processo produtivo e, juntamente com a perda de autonomia do indivíduo sobre qualquer decisão em seu trabalho, contribuiu para reduzir a satisfação do trabalho. $\mathrm{O}$ trabalhador era visto apenas sob aspectos físicos, como fadiga, condições desfavoráveis de trabalho e incentivos financeiros, ignorando o contexto social. O operário era tratado por Taylor como preguiçoso, devendo estar sob controle rigoroso dos supervisores (Bridger, 2009).

Segundo Bridger (2009), o taylorismo pode ter sido adequado no começo do século XX, agindo como um catalisador para a industrialização e produção em massa, mas o seu legado perdura, sobretudo em países em desenvolvimento - mesmo em organizações modernas, os trabalhadores têm pequeno espaço para organizar, programar e completar suas tarefas diárias, por estarem sob rígido controle. Como exemplo, o autor cita que o Serviço Nacional de 
Saúde do Reino Unido introduziu um sistema de gerenciamento que apresenta muitos componentes tayloristas, incluindo a especificação de qual a melhor forma de realizar uma tarefa (incluindo também o tratamento de pacientes), determinando metas para a entrega do serviço, otimização do espaço de trabalho para dar suporte ao método e audições clínicas regulares realizadas por administradores para assegurar que o padrão e as metas estão sendo atingidos. Dependendo do ponto de vista, isso pode ser visto tanto como uma forma de reduzir a autonomia do corpo clínico, quanto como um meio de aperfeiçoar o atendimento aos pacientes (Bridger, 2009).

Apesar de alguns desvios em suas teorias, de um ponto de vista histórico, a teoria de Taylor teve um grande impacto na forma como o trabalho é organizado no mundo, especialmente no que diz respeito ao trabalho industrializado. Segundo Björkman (1996), nenhuma outra doutrina organizacional teve tanta influência no século XX.

Também para a ergonomia, o trabalho de Taylor foi um dos marcos iniciais, pois, de acordo com Moroney (1995 apud Meister, 1999), os conceitos de projeto de tarefas, controle do tempo e estudos de movimentos se tornaram a base para os métodos de análise de tarefas utilizados ainda hoje.

\section{Discussão e considerações finais}

Após a morte de Taylor, os principais seguidores de seu trabalho foram Frank e Lillian Gilbreth, dando à sua teoria o nome de taylorismo. O casal desenvolveu métodos de analisar a forma como as tarefas eram desempenhadas, contribuindo para o conhecimento da eficiência dos movimentos, ainda parte fundamental da engenharia industrial (Bridger, 2009; Meister, 1999).

O fato de o trabalho não estar a critério do trabalhador, quebrando com o método tradicional de certa forma originário de técnicas artesanais e passar para o controle administrativo, foi crucial para o advento de outras técnicas, como a linha de produção de 
Henry Ford. Essa nova postura transferiu o trabalho para um patamar científico, criando uma cultura de que o trabalho deve ser planejado.

Fica evidente que o taylorismo não apresenta contribuições diretas à ergonomia, mas suas teorias deram subsídios para que outros estudiosos da área, analisando o trabalho sob outros aspectos, formassem corpo de conhecimento para o surgimento de novos estudos relacionados ao trabalho, introduzindo o controle de segurança, treinamentos e aperfeiçoamentos sobre a melhor forma de realizar a tarefa.

Além disso, quando o trabalho passa a ser estudado por métodos científicos, surge uma nova especialidade, que posteriormente, e até como forma de reação às condições precárias às quais os trabalhadores eram submetidos, deu surgimento à ergonomia.

É possível, assim, finalizar dizendo que o enfoque comercial que o taylorismo empreendeu à análise do trabalho foi fundamental para suas teorias terem sido aceitas e se expandido rapidamente, com repercussão e aplicação até os dias atuais. Talvez se Taylor tivesse considerado as condições psicológicas do trabalho e voltado o seu enfoque ao trabalhador, e não ao trabalho, suas teorias teriam sido avançadas demais e sem aplicabilidade para o contexto da época.

\section{Referências bibliográficas}

ARNOWITZ, J. DYKSTRA-ERICKSON, E. Observation and interaction design: lessons from the past. Interactions, v. 14, n. 6, 2007.

BJÖRKMAN, T. The rationalization movement in perspective and some ergonomic implications. Applied ergonomics, v. 27, n. 2, p. 11 1-117, 1996. BRIDGER, R. S. An introduction to ergonomics. Boca Raton: Taylor and Francis, 2009.

GONZAGA. R. M.; COELHO. J. M.. Administração científica de Taylor: o Homem do Tempo. Disponível em http:/ / www.administradores.com. br/producao_academica/administracao_cientifica_de_taylor_o_homem_do_tempo/318. Acessado em 1/3/ 2009. 
COOPER, C.; TAYLOR, P. From Taylorism to Ms Taylor: the transformation of the accounting craft. Accounting, organizations and society, v. 25, p. 555-578, 2000.

LAVILLE, A. Ergonomia. Trad.: Márcia Maria Neves Teixeira. São Paulo: Edusp, 1977.

LAZZARESCHI, N. Análise social. Curitiba: IESDE Brasil S.A., 2007. MEISTER, D. The history of human factors and ergonomics. Mahwah: Lawrence Erlbaum Associates, 1999.

RAGO, L. M.; MOREIRA, E. F. P. O que é taylorismo. Brasília: Brasiliense, 1984.

TAYLOR, F. W. Princípios de administração científica. Trad.: ArlindoVieira Ramos. São Paulo: Atlas, 1970. 


\title{
5 \\ A arte do trabalho: Jules Amar
}

\author{
Silvana Aparecida Alves \\ Frederico Reinaldo Corrêa de Queiroz \\ José Carlos Plácido da Silva \\ Luis Carlos Paschoarelli
}

\section{Introdução}

Segundo Dul e Weerdmeester (2004, p.9), "a fisiologia pode estimar a demanda energética do coração e dos pulmões, exigida para um esforço muscular". Os autores comentam que "no estudo da biomecânica, aplicam-se as leis físicas da mecânica ao corpo humano. Assim, podem-se estimar as tensões que ocorrem nos músculos e articulações durante uma postura ou um movimento".

Os estudos de biomecânica e fisiologia contribuíram para criar um paradigma científico que perdurou desde o início do século XX até o início da sua segunda metade. Já para Menezes; Menezes (2008), esse paradigma "foi consolidado a partir de 1915, quando, na Inglaterra, foi formado um comitê destinado a estudar a saúde dos trabalhadores empregados na indústria de guerra, uma espécie de assistência técnica ao fator humano na indústria".

\section{A importância dos estudos de fisiologia}

A contribuição significativa que os fisiologistas do fim do século XIX proporcionaram para a ergonomia é aquela do desenvolvi- 
mento de vários métodos, técnicas e equipamentos que permitiram mensurar o desempenho físico do ser humano, entre eles destacamse o esfigmógrafo, o cardiógrafo, o pneumógrafo (Vidal, 1994). Simultaneamente ao desenvolvimento desses equipamentos avançavam também no estudo teórico específico do desgaste fisiológico e de energética muscular do homem.

O médico fisiologista francês Etienne-Jules Marey (1830-1904) contribuiu desenvolvendo experimentos fotográficos a partir de 1882, para tanto utilizou uma câmera fotográfica com um obturador circular com fendas que permitiam exposições com intervalos entre 5 e 10 vezes por segundo. Denominou essa técnica de cronofotografia em placa única, na qual fotografava animais (aves, cavalos, entre outros) e o corpo humano, deslocando-se sob um fundo escuro com iluminação solar apenas sobre o corpo.

Com a técnica da cronofotografia a imagem era registrada na forma de uma repetição do corpo do animal ou humano, em diferentes posições e equidistantes, permitindo visualizar os movimentos musculares e ósseos necessários para o deslocamento em diferentes momentos no tempo. Por desenvolver essa técnica, Etienne-Jules Marey é considerado um dos pioneiros da fotografia e da história do cinema.

Etienne-Jules Marey realizou estudos sobre a circulação de aves, cavalos e do homem, registrou estes movimentos por meio da cronofotografia. Desenvolveu pesquisas e criou os equipamentos para realizá-las, como, por exemplo, o miógrafo, que permite avaliar a musculatura do corpo em movimento.

A cronofotografia é uma técnica utilizada nas artes, especialmente no cinema, mas ela foi desenvolvida para ser empregada em estudos de fisiologia por Marey. Essa combinação de ciência e técnica com a arte, criada como uma tecnologia visual para capturar o corpo em movimento, por Marey, foi denominada de "a arte do trabalho" por Jules Amar. 


\section{O fisiologista Jules Amar}

\section{Biografia}

Jules Amar nasceu em 1879 em Túnis, seu pai era judeu argelino naturalizado francês. Jules Amar estudou teologia em Sorbonne, no entanto abandou este estudo para dedicar-se à botânica, à bioquímica e à fisiologia com o mestre Chauveau. Tornou-se assistente do fisiologista Georges Weiss, na Faculdade de Medicina de Sorbonne.

Ao trabalhar com Marey, Amar elaborou o banco de uma bicicleta, equipamento criado por Marey que consistia de um monociclo ergométrico equipado com respirador e ergograma e que foi utilizado por Amar juntamente com a fotografia.

Jules Amar se destaca como um dos precursores da ergonomia, sendo um pesquisador atuante na primeira metade do século XX, diretor do laboratório de investigação do trabalho industrial nas artes nacionais do DES do conservatório e Métier, em Paris, além de ser o idealizador de pesquisas realizadas em laboratório e autor do livro intitulado O motor humano, publicado em 1914, o qual aborda seu estudo científico sobre os dados físicos e fisiológicos relacionados à eficiência e ao desempenho humano nos ambientes de trabalho na indústria.

\section{Repercussão das pesquisas de Jules Amar}

Na França, no início do século XX, Jules Amar criou o primeiro laboratório de pesquisa sobre investigação do trabalho profissional, "Conservatório Nacional de Artes e Medidas", no qual foi diretor e onde realizou estudos dos diferentes tipos de contração muscular (dinâmica e estática) que forneceram as bases da ergonomia do trabalho físico.

Em pesquisa realizada em laboratório sobre o corpo humano como máquina, utiliza métodos ergonômicos e de cronofotografia. O fisiologista ressalta a importância de aplicar princípios de mecâ- 
nica ao estudo do corpo humano, entendido como uma máquina que produz energia, e seu rendimento está associado a questões fisiológicas, ambientais e psicológicas. Jules Amar também contribuiu com pesquisas durante a Primeira Guerra Mundial ao ocuparse da reeducação dos feridos e da concepção de próteses.

Seu livro O motor humano foi publicado na França logo após o início da Primeira Guerra Mundial, porém, devido à eclosão da guerra, sua obra demorou a ser traduzida para o idioma inglês.

$\mathrm{Na}$ Argélia, Jules Amar analisou as ações da luz sobre os seres humanos. Segundo esse pesquisador, um exercício indisciplinado acompanha-se de numerosas contrações sem efeito, o que faz aumentar a fadiga. Analisou também os problemas da fadiga causada pelos efeitos do ambiente (temperatura, ruído, iluminação).

Sobre a relação entre o homem e seu ambiente de trabalho, Amar investigou as pesquisas dos cientistas que diziam que os efeitos da alimentação, da bebida, do sono, de problemas fisiológicos, sociais e morais não influenciavam no desempenho das atividades de trabalho. Jules Amar, ao contrário, afirmava que todos esses fatores somados aos fatores ambientais, tais como a pressão atmosférica, a poeira, a ação solar, a iluminação e os ruídos, interferem no desempenho humano na indústria.

Em seu livro $O$ motor humano, considerado por alguns a primeira obra de ergonomia, descreve os métodos de avaliação e as técnicas experimentais, fornecendo as bases fisiológicas do trabalho muscular e relacionando-as com as atividades profissionais.

Nesse livro Amar descreve os princípios mecânicos gerais do corpo humano como uma máquina. Comenta sobre a energia humana, o rendimento da máquina humana e os efeitos fisiológicos causados pelo trabalho. Com relação à interação homem e ambiente, ele apresenta os resultados dos seus estudos e de outros cientistas que também avaliaram o efeito do trabalho, cognitivos, psicológicos, fisiológicos, sociais e ambientais sobre o corpo humano. Aborda as medidas científicas do corpo humano, a energia produzida e dissipada, e considera o corpo como uma máquina em sua relação com o trabalho industrial. 
Nesse sentido, segundo Guzmán (2008), "Jules Amar, 1914, criou as bases da ergonomia do trabalho físico estudando os diferentes tipos de contração muscular dinâmica e estática. Estudou os problemas de fadiga, os efeitos do meio ambiente, temperatura, ruído e iluminação".

\section{Comparação entre Amar e Taylor}

Jules Amar "verificava, de forma experimental, os princípios apontados por Taylor, então acusados de falta de embasamento. O trabalho de Amar é, nesse sentido, um verdadeiro clássico sobre a fisiologia experimental do trabalho. Suas formulações constituem-se no primeiro dos paradigmas da ergonomia: o homem como transformador de energia, o motor humano, como o próprio autor denomina" (Menezes; Menezes 2008).

A arte e a técnica da cronofotografia forneceram a Jules Amar o equipamento essencial para demonstrar como o trabalho manual poderia ser transformado em uma forma de arte diferentemente dos modelos de desumanização impostos pelo taylorismo e pelo imperativo cronômetro.

O sistema proposto por Frederick Winslow Taylor, conhecido como taylorismo, não foi bem aceito na França. Antes da Primeira Guerra Mundial funcionários das oficinas da empresa Renault fizeram uma greve contra o taylorismo, e, mesmo após a administração da empresa fazer algumas tentativas para limitar sua aplicação, estas não foram suficientes para evitar uma nova greve dois meses depois. As reivindicações dos trabalhadores tiveram apoio de sindicatos e de ergonomistas, inclusive de Jules Amar.

Para se contrapor ao taylorismo, Jules Amar emprega a metodologia da cronofotografia, que concilia as ciências fisiológicas e a arte, por isso foi chamada por Amar de "A arte do trabalho". Amar utilizou a cronofotografia para legitimar seu diagrama ergonômico e o emprego de estatísticas biométricas ao mesmo tempo. 


\section{Discussão e considerações finais}

Os estudos dos fisiologistas no fim do século XIX e primeira metade do século XX, especialmente o trabalho que Jules Amar desenvolveu, resultaram em grande contribuição para a ergonomia. Esse período é marcado pelas experimentações realizadas em laboratórios e estudos de campo, sobre a contração muscular, a energia despendida para exercer o trabalho, a fadiga e o desempenho humano na realização de tarefas profissionais.

Todas as atividades de pesquisa eram regidas com rigor científico. Alguns métodos e técnicas como o esfigmógrafo, o cardiógrafo, o pneumógrafo e a cronofotografia desenvolvidos por Marey foram aplicados por Jules Amar. Esses métodos conciliavam a ciência, a técnica e a arte, como a técnica da cronofotografia denominada por Jules Amar de "A arte do trabalho", e por ele empregada em seus experimentos.

As pesquisas desse período compreendem um estudo amplo da ergonomia que transcende a fisiologia e a psicologia, e envolve inclusive uma avaliação dos aspectos sociais e políticos. Os estudos sobre a ergonomia em sentido amplo resultaram em contribuições significativas para os tempos atuais.

\section{Referências bibliográficas}

DUL, J.; WEERDMEESTER, B. Ergonomia prática. $2^{a}$ ed. rev. e ampl. São Paulo: Edgard Blücher, 2004.

GUZMÁN, O. B. G. Ergonomía y terapia ocupacional. TOG. 05(01): 23p. 2008.

MENEZES, W. J. de; MENEZES, F. H. O. de. Ergonomia: conceitos introdutórios e noções de sistema informacional. 2008. Disponível em http://www.fortium.com.br/faculdadefortium.com.br/wladimir_jatoba/material/4623.doc. Acessado em 4/3/2010.

VIDAL, M. C. Os paradigmas em ergonomia: uma epistemologia da insatisfação ou uma disciplina para a ação? Grupo de Ergonomia e Novas Tecnologias - GENTE da COPPE/UFRJ, Rio de Janeiro, 1994. 


\title{
6 \\ A ORIGEM DA ERGONOMIA NA EUROPA: CONTRIBUIÇÕES ESPECÍFICAS DA INGLATERRA E DA FRANÇA
}

\author{
Ana Clara Fernandes Láuar \\ Marcos José Alves de Lima \\ Verena Ferreira Tidei de Lima \\ José Carlos Plácido da Silva \\ Luis Carlos Paschoarelli
}

\section{Introdução}

As ações de adaptação do meio realizadas pelo homem pré-histórico e, no decorrer de sua evolução, o elevado número de ações isoladas em tempos e pontos geográfica e culturalmente distintos foram fatores que contribuíram para a formação da ergonomia.

Certamente, nas culturas antigas, clássicas e românicas esses fatores foram se organizando, mas não havia nesses períodos, ainda, uma preocupação de se estudar ou sistematizar as atividades humanas.

É com o Renascimento europeu que se inicia os estudos sistemáticos nessa área, com destaque para Da Vinci (1452), Ramazzini (1700), Jastrzębowski (1857) e, mais ultimamente, Taylor (1903), Gilbreth (1900), Chapanis (1943), entre outros, os quais se dedicaram a tornar científico o conhecimento das inúmeras variáveis da dinâmica do trabalho, do corpo, da produção, do movimento, etc. Essa fase da ergonomia é denominada precursora ou gestacional.

Entretanto, além dos brilhantes expoentes supracitados, não se devem esquecer as condições históricas e geográficas que vivenciaram, as quais devem ter contribuído de modo decisivo para 
que a ergonomia tivesse seu desenvolvimento e fosse apresentada e formatada atualmente.

Na Europa, as abordagens ergonômicas a respeito do trabalho são antigas, mas deve-se aos ingleses sua origem, tanto do conceito quanto do conteúdo e forma de abordagem, caracterizando-se, assim, como uma disciplina autônoma. O tema iniciado então por Jastrzebowski é retomado quase cem anos depois, quando em 1949 acontece a primeira reunião do grupo de pesquisadores para retomada dos estudos sobre ergonomia, interessados em formalizar a existência desse novo ramo de aplicação interdisciplinar.

Além da Inglaterra, a França é um país de intensa participação na construção e consolidação da ergonomia. A Inglaterra, em função de Kenneth Frank Hywel Murrell e da Ergonomics Research Society, e a França, em função da Societé d'Ergonomie de Langue Française, ambas entidades relevantes na história da ergonomia.

\section{Inglaterra: Murrell e a Ergonomics Research Society}

Kenneth Frank Hywel Murrell nasceu em 1908 e formou-se em Química. Sua experiência nas forças armadas o levou a observar as condições das atividades humanas. Em 1949, Kenneth Frank Hywel Murrell define ergonomia como "o estudo da relação entre o homem e o seu ambiente de trabalho" e, no mesmo ano, convida um pequeno grupo de pessoas que compartilhavam de observações e opiniões semelhantes e que tinham experimentado pesquisas sobre fatores humanos para uma reunião, a fim de discutirem o assunto em um aspecto mais formal.

A partir desses encontros, em Londres, é que se estabeleceu a Human Research Society, que meses depois iria se tornar a Ergonomics Research Society (Browne, 1950). Participaram dessa entidade cientistas de diversas áreas: fisiologistas, psicólogos, engenheiros, entre outros, e no fim da década de 50 ela já contava com aproximadamente 200 membros. 
A Sociedade evoluiu rapidamente com a realização de encontros como simpósios, seminários e conferências, e também ações paralelas de seus membros.

Kenneth Frank Hywel Murrell forma, no início dos anos 1950, o primeiro Departamento de Ergonomia na indústria, Tube Investments Ltd., e, em 1954, ingressa na Universidade de Bristol e passa a liderar um grupo de estudos sobre fatores humanos. Posteriormente, envolve-se com outros grupos de pesquisa, mas sempre associados às questões ergonômicas.

A Ergonomics Research Society lança, em 1957, o periódico "Ergonomics", o qual teve como editor A. T. Welford.

Em 1958, em reunião com o Department of Science and Industrial Research, inicia-se a discussão sobre a formação de ergonomistas, tendo em vista a dificuldade de definição de ergonomia. Já em 1959 surge o primeiro curso de graduação em Ergonomia, na Universidade de Loughborough, e, nesse mesmo ano, surgem as principais divergências entre os estudos de engenheiros e de ergonomistas, assim como problemas em definir especificamente o que realmente se entende pelo termo ergonomia.

Kenneth Frank Hywel Murrell publica, em 1960, o primeiro livro sobre ergonomia, intitulado Ergonomics: Fitting the Job to the Worker. Em 1959 é fundada, em Oxford, a International Ergonomics Association (IEA). Seus estatutos foram aprovados na primeira assembleia geral, que se realizou em Estocolmo, em 1961, tendo Kenneth Frank Hywel Murrell e O. G. Edholm em seu comitê. Atualmente a Associação representa as associações de ergonomia em quarenta países, com um total de 15.000 sócios.

\section{França: a Societé d'Ergonomie de Langue Française}

Na França, a ergonomia se desenvolveu principalmente nos setores de pesquisa e ensino público, particularmente associados ao Conservatório Nacional de Artes e Ofícios (Cnam), ao Centro Nacional de Pesquisa Científica e à Escola Prática de Altos Estudos. 
A Societé d'Ergonomie de Langue Française (Self) foi fundada em 1963, e teve seu estatuto aprovado por seus nove membros fundadores. Sua criação pode estar relacionada a dois fatores que ocorreram a nível internacional, nos anos que a precederam.

Em primeiro lugar, entre 1956 e 1959, o projeto "Adaptação do Trabalho ao Homem da Agência Europeia de Produtividade", com iniciativa conjunta do Ministério do Trabalho e da Comissão Nacional de Planejamento e Produtividade, possibilitou conhecer franceses que poderiam dar contribuições ao projeto. Destacam-se a realização de um seminário internacional na Holanda, em 1957, e uma conferência internacional com empresários, sindicatos e profissionais das ciências aplicadas ao trabalho humano, na Suíça, em 1959. Nesse contexto, em 1958 é publicada a obra de Jean-Marie Faverge, Jacques Leplat e Bernard Guiguet, intitulada A Adaptação da Máquina ao Homem e fundamentada em seus trabalhos no Centro de Estudos e Pesquisas Psicotécnicas e em suas intervenções em dois dias de seminários organizados nos centros produtivos de doze cidades francesas.

Em segundo lugar, Paul Albou, então responsável pela Comissão Nacional de Planejamento e Produtividade, solicitou das indústrias informações nesse campo, o que contribuiu de forma muito eficaz para a criação da Self e ao financiamento para novas pesquisas na área.

Em 1961, o primeiro congresso da Associação Internacional de Ergonomia reuniu cerca de vinte participantes franceses. Eles teorizaram sobre uma combinação entre o francês e a ergonomia, para que participassem, posteriormente, da Associação Internacional de Ergonomia. E, mesmo antes disso, vários deles haviam participado de conferências e congressos da Ergonomics Research Society.

Em 1955, é publicada a obra Análise do Trabalho, de Obredane e Faverge, que se torna decisiva para a evolução da metodologia ergonômica. Nessa publicação é apresentada de forma clara a importância da observação das situações reais de trabalho para a melhoria dos meios, métodos e ambiente do trabalho.

Desde 1966, Alain Wisner - médico, psicólogo e professor - dirige o "Laboratório de Ergonomia e Neurofisiologia do Trabalho" 
do Conservatório Nacional de Artes e Ofícios, vinculado ao Ministério da Educação da França, em Paris (Wisner, 1987). Sua perspectiva ergonômica, sempre predominante em sua carreira, o fez criar o primeiro laboratório industrial de ergonomia francês, na Régie Renault, e, desde então, tornou-se professor de ergonomia, oferecendo várias modalidades de cursos em ergonomia para estudantes e profissionais de empresas da França e de mais outros trinta países. No Conservatório Nacional, Jules Amar cria o primeiro laboratório de pesquisa sobre o trabalho profissional e, desse modo, a fisiologia do trabalho encontra uma estrutura para se desenvolver (Laville, 1977).

\section{Outras contribuições}

Como citado anteriormente, a IEA foi fundada em 1959, em Oxford, Inglaterra. Sua criação está intimamente ligada aos projetos iniciados pela European Productivity Agency (EPA), contribuindo também com a criação da Self. A EPA apresentou, em 1957, um conjunto de propostas para a formação de uma associação internacional de cientistas do trabalho. Um Comitê foi indicado para desenvolver as propostas, e acabou por organizar uma associação denominada International Ergonomics Association. Posteriormente, em 1959, em uma conferência realizada pela EPA em Zurique, na Suíça, o Comitê (que havia se autonomeado "Comitê para a Associação Internacional de Cientistas de Ergonomia”) decidiu manter a denominação prévia. Finalmente, em 6 de abril de 1959, em Oxford, Inglaterra, foi declarada a fundação da IEA, cujos estatutos foram aprovados em sua primeira assembleia geral, em 1961, na cidade de Estocolmo, Suécia.

Atualmente, fazem parte da IEA 47 sociedades federadas, 2 sociedades afiliadas, 7 membros organizacionais e 2 membros individuais.

Além da ERS e da IEA, na Inglaterra, inicialmente o ensino e a pesquisa localizaram-se em menor escala no setor público: o mesmo ocorreu na Bélgica, Suíça e Holanda, onde os centros de ergonomia são numerosos e ativos. $\mathrm{O}$ aspecto da higiene industrial 
é um elemento importante em todos esses países e são justamente os problemas industriais que lhe fornecem o campo de aplicação e os temas de pesquisa.

No leste europeu, a ergonomia se implantou com certo atraso. Mas seu desenvolvimento acelerado faz com que ela desempenhe importante papel no estabelecimento dos conhecimentos e na passagem para sua aplicação (Laville, 1977).

\section{Discussão e considerações finais}

Foram exatamente as inquietações e divergências em sua definição que possibilitaram o surgimento e crescimento da ergonomia, principalmente nas sociedades criadas em meados do século XX, destaque para a Ergonomics Research Society, na Inglaterra, e a Societé d'Ergonomie de Langue Française, na França.

As discussões sobre o que era de maior importância - a pesquisa ergonômica e a divulgação de seus resultados ou o desenvolvimento e aplicação da ergonomia na indústria - de certa forma fizeram com que ambas as coisas acontecessem e evoluíssem

A publicação de periódicos e a realização de encontros anuais, tais como conferências, possibilitaram a expansão dos estudos e fomentaram a adesão de novos membros. Atualmente a International Ergonomics Association contribui de forma decisiva para a expansão da ergonomia em todo o mundo.

\section{Referências bibliográficas}

BROWNE, R. C.; DARCUS, H. D.; ROBERTS, C. G.; CONRAD, R.; EDHOLM, O. G.; HICK, W. E.; FLOYD, W. F.; MORANT, G. M.; MOUND, H.; MURRELL, K. F. H.; RANDLE, T. P. Ergonomics Research Society. British Medical Journal. 01(_):1009. 1950.

LAVILLE, A. Ergonomia. São Paulo: EPU, 1977.

WISNER, A. Por dentro do trabalho. Ergonomia: método \& técnica. São Paulo, Oboré, 1987. 


\title{
7 \\ DeSENVOLVIMENTO DA ERGONOMIA NA RÚSSIA (EX-URSS): ESTUDOS APLICADOS À INDÚSTRIA E À AERONÁUTICA
}

\author{
João Carlos Riccó Plácido da Silva \\ Danilo Corrêa Silva \\ Luciane do Prado Carneiro \\ José Carlos Plácido da Silva \\ Luis Carlos Paschoarelli
}

\section{Introdução}

O início do século XX foi marcado pela I e II Guerras Mundiais. Nesse período, além da necessidade de desenvolver armamentos rapidamente, foi preciso criar sistemas de comunicação e controle mais avançados. O que se percebeu nesse período foi que muitos desses equipamentos não se adaptavam às características dos seres humanos que os operavam, provocando erros e acidentes, que poderiam ser graves e, consequentemente, levar à morte.

Em períodos de guerra, a perda de combatentes gera problemas sérios para as forças armadas. Assim, estudos e pesquisas começaram a ser desenvolvidos por engenheiros, médicos e cientistas, a fim de desenvolver e modificar os projetos de comandos (alavancas, botões, pedais, etc.) e painéis, além do campo visual das máquinas de guerra. Com isso foi iniciada a adaptação de tais equipamentos aos operadores, pois o uso desses artefatos se dava em condições críticas, ou seja, em combate.

Com o fim das grandes guerras, os estudos ergonômicos continuaram a ser desenvolvidos por diversos profissionais, que se reuniram na Inglaterra para apresentar suas ideias e teses. Também 
já existiam laboratórios de ergonomia montados na marinha e força aérea dos Estados Unidos, onde começou a ser conhecida por human factors (fatores humanos).

Posteriormente, com o começo da guerra fria e a corrida espacial entre a União das Repúblicas Socialistas Soviéticas (URSS, atual Rússia e demais estados independentes) e os EUA, os estudos ergonômicos ganharam um grande impulso junto à Agência Espacial Norte-Americana (Nasa) e ao Centro de Estudos Aeroespaciais da URSS, começando a ser aplicados pelas indústrias de toda a América do Norte, da Europa e, posteriormente, de todo o mundo.

\section{O início da ergonomia na URSS}

Wojciech Yastrzebowski utilizou o termo "ergonomia” pela primeira vez em 1857. Yastrzebowski foi um naturalista polonês, e destacou-se como um dos predecessores da ergonomia no que viria a se tornar a URSS.

Outros precursores conceituais da ergonomia russa incluem: Mendeleev, que discutiu em 1880 a noção geral de adaptação das máquinas ao homem; Arendt, que em 1888 discutiu o conceito de adaptação em relação ao desenvolvimento da aeronáutica; Rudnev, que em 1915 levantou questões sobre o desenvolvimento de cockpits padrões para aeronaves; e Rosenberg, que em 1928, usando dados antropométricos, determinou os requisitos de um cockpit (Meister, 1999).

Na discussão sobre o desenvolvimento da ergonomia na Rússia, Lomove e Bertone (1969 apud Meister, 1999) não mencionaram nada sobre a ligação da human factors e as duas grandes guerras mundiais. Esses autores citaram vários exemplos precoces do que hoje se chama ergonomia: Gellerstein e Ittin, em 1924, a respeito do redesenho das fontes russas para melhor funcionamento das impressoras tipográficas; Bernstein, em 1929, a respeito do redesign de postos de trabalho de estações elétricas. 
Prosseguem com Platonov e Mikhailovskii, que em 1934 discutiram cadeiras ajustáveis para mecânicos automotivos. Em 1937, Zimkin e Aeple usaram um taquistoscópio (aparelho destinado a examinar a rapidez da percepção visual e a explorar o seu campo, trata-se de um cartão plástico com quatro janelas) para estudar a recepção de informações de instrumentos de aviação.

Numa conferência de 1921 para a organização científica do trabalho e da indústria, o psicólogo soviético V. N. Myasishchev propôs a criação de uma disciplina especial chamada ergologia - o estudo do trabalho humano. Outros pesquisadores conduziram o trabalho que pode ser classificado como ergonomia na primeira metade do século XX, mas o desenvolvimento dessa disciplina começou oficialmente em torno dos anos 1950 (Munipov, 1978 apud Seminara, 1979).

A ergonomia soviética foi severamente afetada por mudanças políticas que seguiram à Revolução de 1917. Nas décadas de 1920 e 1930, o impulso foi dado por muitos psicólogos, alguns deles especializados em fisiologia. No entanto, após a Revolução, houve grande crítica e pressão para introduzir o pensamento marxista na psicologia. Isso levou ao fechamento de vários laboratórios, à prisão e até mesmo execução de muitos psicólogos (Meister, 1999).

Porém a necessidade de reconstrução após a Segunda Grande Guerra e o início da Guerra Fria deu novo impulso à pesquisa em psicologia. De 1950 a 1958, Platonov lecionou pelo Departamento de Psicologia na Universidade de Moscou. Em 1962, ocorreu a primeira conferência de filósofos, fisiologistas e psicólogos, na qual a psicologia do trabalho foi muito discutida.

O primeiro laboratório de engenharia psicológica foi estabelecido em 1959, a partir de esforços de Boris F. Lomov, na Universidade de Leningrado. Pouco depois, em 1960, um laboratório de ergonomia foi criado no Instituto de Técnicas Estéticas do Laboratório de Engenharia Psicológica, na Universidade de Moscou. Nesse período, atividades de engenharia e psicologia também eram desenvolvidas na Universidade de Kharkov e no instituto da investigação psicológica em Kiev. A primeira conferência envolvendo 
essas áreas aconteceu em 1967, sendo considerada pelos soviéticos como o início oficial da ergonomia na URSS.

Foram realizados diversos esforços para caracterizar a ergonomia como ciência. Esses esforços foram críticos devido à precária posição política da disciplina. Os pesquisadores justificavam a existência da ergonomia à base do militarismo, afirmando que muitos erros cometidos por combatentes eram causados por deficiências na interface com os equipamentos. Apresentavam muitos exemplos de designs precários de controles e mostradores, preparando dados normativos para estabelecer padrões para equipamentos militares e conduzindo estudos experimentais com pessoal militar em atividades de trabalho.

Todos esses esforços foram profundamente influenciados pela literatura da Europa ocidental e americana. Muitas publicações do ocidente foram traduzidas no período de 1970 a 1980, incluindo livros de Chapanis, Woodson, Siegel e Wolf, e Sheridan e Ferrel. Nesse período, algumas informações dos conceitos russos também começaram a ser disponibilizadas no ocidente (Meister, 1999).

Na década de 1970, Lomov foi para Moscou, onde criou e chefiou o Instituto de Psicologia. Dentro desse instituto, foram estabelecidos o Departamento de Engenharia Psicológica e o Departamento de Psicologia do Trabalho, ambos chefiados por Valery Venda, vindo do Instituto de Técnicas Estéticas. Também durante esse período, na Universidade de Yaroslavl, foi estabelecido um programa de formação acadêmica para os ergonomistas e engenheiros psicólogos.

Em 1979, cerca de dois mil indivíduos estavam envolvidos em alguma pesquisa ou atividade ergonômica na URSS, sendo ligados a universidades, institutos de pesquisa, institutos de design, agências de transporte, organizações militares ou laboratórios industriais. A Conferência de Engenharia e Psicologia, realizada em 1974 na Universidade de Yaroslavl, atraiu três mil representantes, sendo em grande parte engenheiros (Seminara, 1979).

Os estudiosos engajados na ergonomia da época se constituíam aproximadamente por: $50 \%$ de psicólogos de diferentes áreas (en- 
genharia psicológica, psicólogos industriais, especialistas em treinamento e psicólogos sociais); $40 \%$ de fisiologistas por formação, que se concentraram nas atividades de trabalho; e os 10\% restantes são de uma variedade de disciplinas, como antropólogos, médicos clínicos e higienistas.

A ergonomia na URSS conseguiu apoio do Estado se valendo de objetivos comuns da Guerra Fria, como a contribuição para o avanço da tecnologia (inclusive a energia nuclear, Figura 3) e o desenvolvimento industrial, da mesma forma que os fatores humanos foram abordados nos EUA. Lomov e Bertone (1969, apud Seminara, 1979) destacam inclusive que essa disciplina relativamente nova foi discutida no XXIII Congresso do Partido Comunista em conjunto com o desenvolvimento da economia nacional de 1966 a 1970.

\section{Principais diferenças entre a ergonomia soviética e a ocidental}

Embora houvesse influência do "ocidente", a ergonomia soviética não foi uma cópia exata do que era desenvolvido no resto do mundo. Na URSS, a matemática e a física eram muito sofisticadas e tiveram grande influência no desenvolvimento das suas linhas de pensamento. Os pesquisadores soviéticos dedicaram muito tempo ao desenvolvimento de métodos matemáticos para formalizar a teoria ergonômica. Entretanto, o efeito prático dessa influência foi limitado (Meister, 1999).

Embora bem similares, diferenças marcantes na terminologia podem ser notadas entre os estudos. Os conceitos são basicamente os mesmos, mas a terminologia diferiu para se adequar a preceitos da ideologia marxista. Uma diferença marcante também é encontrada na profundidade e detalhes entre as duas linhas de pensamento. Os pesquisadores soviéticos descreveram exaustivamente o comportamento e desempenho, tanto em aspectos sensórios-motores, perceptuais, cognitivos, motivacionais e emocionais. 
Devido a essa atitude multifocal, os soviéticos se preocuparam mais com o contexto da tarefa e o estado interior do indivíduo do que os seus contemporâneos do ocidente, que se ocupavam dos aspectos críticos do desempenho. Por exemplo, se os primeiros fossem descrever o ato de acionar um interruptor, eles abordariam os aspectos do objetivo de acionar, a motivação do operador, a percepção sobre o interruptor, a imagem do interruptor na consciência do operador, a estratégia utilizada no acionamento, a resposta muscular dada pelos braços, o feedback recebido pelo operador e se o objetivo foi alcançado.

A ergonomia soviética também foi muito influenciada pela psicologia cognitiva, filosofia, fisiologia e cibernética. A ligação com a filosofia pode ser notada na definição do conceito de vontade ou motivação (do inglês will), cujos pesquisadores americanos não consideraram durante as duas primeiras décadas do século XX, até o advento do behaviorismo de Watson. A influência da fisiologia é sugerida pela tendência de notabilizar o sistema neurológico e condições cerebrais pelo comportamento. O impacto da cibernética é visível na maneira pela qual eles descrevem as funções, como se fossem escritas em linguagens de programação computacionais.

A teoria da atividade (deytolnost) é a base da ergonomia na URSS. O conceito de atividade é definido como um sistema de processos mentais internos, comportamentos externos e motivacionais que são combinados e direcionados para alcançar metas objetivas e conscientes. A principal distinção entre essa abordagem e o behaviorismo de Watson é a existência de uma meta consciente, tanto perceptual quanto cognitiva, que determina a especificidade da seleção de informação e estratégia do seu conhecimento. Uma pessoa não reage ao estímulo ou à simples informação, mas age ativamente em uma dada situação baseada nas metas e nos motivos existentes.

O conceito russo de atividade de trabalho é altamente motivacional, no qual as metas têm grande importância. Os conceitos ocidentais de meta sugerem que na maioria das atividades ela é evidente ao operador. No entanto, para o pensamento soviético ela 
é imagem do resultado desejado no futuro, a meta pode ou não ser aparente, e, mesmo quando é evidente, o operador examina a meta e então desenvolve um senso dela e uma estratégia para alcançá-la. Isso se aplica mesmo quando a tarefa é puramente psicológica.

Outra peculiaridade da ergonomia soviética é que os profissionais eram muito mais preocupados com fatores temporais do que os ergonomistas ocidentais. Os soviéticos usaram o tempo como meio de avaliar o sistema, assim como estudar o processamento de informação. A análise detalhada de microações feitas pelos psicólogos soviéticos leva a um interesse em sistemas de tempo predeterminado, tal como o MTM-1 (Meister, 1999), embora nem todos os teóricos soviéticos o utilizassem.

$\mathrm{Na}$ atividade de trabalho, o índice de tempo emerge como um dos critérios mais importantes de produtividade e eficiência do trabalho. A falha da função por limite de tempo é vista como uma falha humana no sistema homem-máquina. Os ergonomistas soviéticos viam o tempo como o mais objetivo e simples método de mensurar o desempenho humano. O tempo não apenas reflete as características distintivas do comportamento externo, mas também especifica o processo psíquico interno.

A análise voltada para o design seguia o mesmo padrão sistemático, iniciando-se com o desenvolvimento de algoritmos para descrever o sistema a ser desenvolvido. Um algoritmo é geralmente um princípio, comumente em forma de equação, que contém variáveis cujos valores, quando modificados, permitem que ele seja aplicado em várias situações que os envolvam.

Os algoritmos soviéticos são altamente sistematizados, podendo ser utilizados para descrever como os componentes do sistema se relacionam, além de poder ser descritos como uma tabela, símbolo ou gráfico. Para criar esses algoritmos, era desenvolvida uma descrição verbal da tarefa e suas metas, estímulos e desempenho, condições e relacionamentos temporais das suas ações. A tarefa é então dividida em suas ações elementares e condições lógicas, sendo cada uma designada por símbolos; cada símbolo é associado, portanto, a uma tarefa específica, como girar um volante. 
Os ergonomistas soviéticos utilizaram algoritmos para descrever, analisar, avaliar e como auxílio ao processo de design. No entanto, essa ferramenta poderia tornar a análise de tarefas simples muito complexa devido à necessidade de decompô-la em ações elementares. Meister (1999) aponta ainda que alguns algoritmos soviéticos tendem a generalizar ou tratar de forma simplista fenômenos complexos, como o stress.

Portanto, as diferenças entre a ergonomia soviética e a ocidental estão principalmente na terminologia e profundidade com que os aspectos são abordados, ou seja, o foco de análise (como a ênfase no tempo e a análise molecular). Além disso, os soviéticos, talvez pela forte participação da psicologia na formação dessa ciência, enfatizaram aspectos motivacionais e contextuais da tarefa. Porém, a maioria dos conceitos adotados é similar em ambas as teorias.

\section{Ergonomia na aeronáutica e programa espacial: contribuição de Vladimir Popov}

O pioneiro dos estudos relacionados à ergonomia na aeronáutica e sistema espacial foi Vladimir Popov, que dirigiu o Laboratório de Problemas Especiais sob o Departamento de Psicologia do Trabalho do Instituto de Psicologia de Moscou. Ele identificou muitos aspectos ergonômicos relevantes na aviação e nos sistemas espaciais, além disso, participou do programa espacial soviético da época.

Relacionou algumas situações problemáticas que surgiram a partir de recomendações ineficazes feitas por engenheiros psicólogos. Ele atribuiu isso ao fato de que os dados obtidos em estudos laboratoriais não eram suficientemente representativos do ambiente operacional. O principal problema identificado foi a falta de fidelidade na simulação, tanto para os estudos do programa espacial como para a aviação. Esses estudos não consideraram fatores como o confinamento e fatores sociais, interações e tripulação.

Popov ressaltava que as recomendações seriam mais eficazes se o operador humano fosse observado em um ambiente similar ao 
espaço de trabalho real. O esforço de seu grupo de pesquisa foi direcionado ao desenvolvimento de métodos que permitissem estimar a qualidade da tarefa executada e o estado fisiológico e psicológico do operador (Seminara, 1979).

Várias simulações espaciais e controles de aviação complexos foram desenvolvidos sob seu comando em laboratórios. Apesar dos altos custos dos simuladores, os financiamentos eram conseguidos devido à utilização dos resultados por vários institutos. Verificou também que era possível gerar um stress real em laboratório sem grandes problemas, visando investigar como os operadores lidavam com a situação de crise em um ambiente controlado.

Esse grupo também teve grande interesse nos problemas de orientação espacial em aviões, no mar e no espaço. Aspectos biomédicos da área também foram estudados, mas havia pouca informação disponível em relação ao desempenho do operador. Para isso a literatura norte-americana foi seguida atentamente. A sua participação também se estendeu ao programa de treinamento de pilotos, avaliando principalmente como eles deveriam se portar em situações de mau tempo.

Esse foi o primeiro estudo na área que indicou mudanças básicas para um sistema, apontando possíveis soluções para os problemas de projeto nas cabines dos pilotos. Impressionado pelo desinteresse de outros cientistas, convenceu os psicólogos a o apoiarem na persuasão do diretor do programa espacial. Os astronautas soviéticos participaram ativamente do projeto e da construção dos veículos espaciais, assim como os astronautas americanos. Entretanto, após o voo, esses indivíduos não tinham muito tempo para relatar os problemas detectados, uma vez que participavam de muitos eventos públicos, o que acarretava na perda das informações.

\section{O Instituto para a Técnica Estética (VNIITE)}

O Instituto de Investigação da União para a Técnica Estética, conhecido pela sigla VNIITE, tinha como vice-diretor Vladimir 
Munipov, representante do setor de desenho industrial. Munipov era especialista em engenharia psicológica e ergonomia e escreveu muitas publicações nestas áreas. Em 1978 publicou uma descrição de atividades ergonômicas no VNIITE e em outras partes da URSS também.

Dentro desse instituto, em Moscou, foi implantado um departamento de ergonomia com uma equipe de 60 pessoas. OVNIITE era dividido em nove setores e também trabalhava com cerca de 1.000 outros institutos de design da URSS. A filosofia desse instituto propunha que o desenho industrial se tornasse um meio ativo de transformar o ambiente, ajudando a criar as condições adequadas para o desenvolvimento harmonioso dos homens na sociedade socialista.

A principal tarefa de um projeto socialista é a formação de um ambiente capaz não só de criar as condições de bem-estar material, mas também de enriquecer espiritualmente o homem, ou elevar seus padrões estéticos. Por decreto do governo soviético todos os bens eram para melhorar a vida humana. Segundo Munipov "o consumidor não deve conseguir o que ele pede, mas sim o que ele precisa. Ergonomia é vista como uma parte integrante do desenho industrial" (Seminara, 1979).

OVNIITE concedia um selo que certificava a qualidade, sendo atribuído aos produtos que passavam pelos seus testes de qualidade, realizados nos laboratórios do departamento de ergonomia. Eles avaliavam uma variedade de bens de consumo, como, por exemplo, as cadeiras para os operadores e as diferentes formas de controles e mostradores de consoles.

O departamento de ergonomia dispunha de uma série de laboratórios considerados essenciais para a análise de situações ocupacionais. Entre os mais destacados havia: uma câmara de isolamento de ruído com instrumentos de gravação; um laboratório para avaliações do espaço físico de trabalho e fatores antropométricos; e também um laboratório que tratava da capacidade visual do usuário, sendo este projetado principalmente para a investigação do movimento dos olhos.

Devido a esse suporte, os engenheiros e projetistas sempre se referiam ao departamento de ergonomia quando buscavam orien- 
tações do VNIITE. Além disso, havia estudos específicos para as centrais de controle de usinas elétricas e desenvolvimento de layouts dessas centrais. Segundo o psicólogo Zinchenko, "se o gestor do programa for inteligente, ele utilizará os esquemas oferecidos pelo departamento de ergonomia" (Seminara, 1979), ressaltando os casos em que os engenheiros soviéticos aceitaram algumas recomendações e onde elas foram rejeitadas.

Munipov também desenvolveu um manual de ergonomia, intitulado "Ergonomia: princípios e recomendações", que foi montado em duas partes: uma destinada aos ergonomistas e a outra aos designers. Esse texto foi completado em 1980 com a pretensão de que servisse de base para a padronização da ergonomia, com enfoques, critérios e métodos de avaliação.

\section{Discussão e considerações finais}

A ergonomia soviética foi severamente afetada por mudanças políticas que se seguiram à Revolução de 1917. A psicologia, área da qual foram apropriados diversos métodos de observação e análise das tarefas executadas pelos usuários, sofreu diversos golpes do regime instaurado, que a considerava como uma interferência burguesa na realidade. Porém a necessidade de reconstrução após a Segunda Grande Guerra e o início da Guerra Fria deu novo impulso à pesquisa em psicologia.

A partir do estabelecimento dessa nova área do conhecimento, foram realizados diversos esforços para caracterizar a ergonomia como ciência. Esses esforços eram centrados principalmente no militarismo, utilizando a ergonomia como possível solução para deficiências na interface com os equipamentos. Os pesquisadores apresentavam muitos exemplos de designs precários de controles e mostradores, e conduziam estudos experimentais com pessoal militar em atividades de trabalho.

Houve grande influência das publicações da Europa ocidental e americana, utilizando muitas obras traduzidas no período de 1970 a 
1980, incluindo livros de Chapanis, Woodson, Siegel e Wolf, e Sheridan e Ferrel. No entanto, a ergonomia soviética, apesar de utilizar alguns conceitos semelhantes, utilizou terminologia própria para as suas definições, principalmente por motivos políticos.

A análise ergonômica e o desenvolvimento de metodologias projetuais nela baseados levaram em consideração aspectos relativamente mais amplos que os seus contemporâneos ocidentais, como, por exemplo, os aspectos relativos à motivação e interpretação da tarefa por parte do operador. Além disso, cada tarefa era decomposta matematicamente em suas ações mais elementares, fazendo com que mesmo as tarefas mais simples pudessem se tornar complexas de analisar.

Destaca-se ainda a importância dos estudos ergonômicos de Popov, envolvendo painéis de comando complexos e com grande número de acionamentos, voltados para a aviação e área espacial soviética. A sua preocupação em realizar suas análises laboratoriais em condições próximas às reais levaram ao desenvolvimento de métodos e resultaram em recomendações mais eficazes.

Por fim, desde a utilização do termo ergonomia, realizada pela primeira vez em 1857, pelo polonês Wojciech Yastrzebowski, são inúmeros os relatos de estudos envolvendo fatores ergonômicos, seja no projeto de estações de trabalho, seja na produção de dispositivos ou ferramentas mais eficientes a partir de dados antropométricos.

\section{Referências bibliográficas}

MEISTER, D. The history of human factors and ergonomics. Ed. Lawrence Erlbaum Associates, Inc. Mahwah: 382p, 1999.

MUNIPOV, V.; ZINCHENKO, V.; MUNIPOV, M. The influence of Bartlett's work on Soviet and Russian ergonomics. Ergonomics (01) vol. 51: pp.35-41, 2008.

SEMINARA, J. L. Human factors in the URSS, part I. Applied ergonomics (04) v. 10: pp.201-210, 1979. Human Factors in the URSS, part II. Applied ergonomics (01) v. 11: pp.23-30, 1980. 


\title{
8 \\ ORIGEM DA HUMAN FACTORS NOS Estados UnIDOS DA AmÉRICA
}

\author{
Alexandre Perussi \\ Frederico Queiroz \\ Rafaela Santana Balbi \\ José Carlos Plácido da Silva \\ Luis Carlos Paschoarelli
}

\section{Introdução}

O surgimento da ergonomia não pode ser definido com precisão, mas sua evolução conceitual se deu em consequência da concepção e problemas operacionais apresentados pelos avanços tecnológicos dos últimos séculos.

De fato, "... a aplicação dos conhecimentos parciais e empíricos aos problemas do trabalho é muito antiga..." (Laville, 1977, p.1) e a preocupação do homem em adaptar o ambiente e construir objetos artificiais para atender às suas conveniências sempre esteve presente. Por outro lado, foi principalmente durante a Revolução Industrial, ocorrida a partir do século XVIII, que a necessidade de adaptar as atividades ocupacionais às necessidades humanas se tornou um problema maior com a existência das primeiras fábricas que não ofereciam condições de salubridade aos trabalhadores (Iida, 2005).

Na maioria das nações em que houve industrialização, a preocupação com os sistemas de produção e, como consequência, com as tarefas e atividades do trabalhador tornou-se uma prerrogativa para os estudos nessa área. Nos Estados Unidos da América (EUA) esse processo foi muito expressivo, especialmente com a denominada human factors engineering. Entre os destaques, estão os grandes 
impactos no âmbito militar e depois no aeroespacial (Laville, 1977, p.10), o que sugere que essa evolução pode ser dividida em dois períodos, aquele durante a I Guerra Mundial e aquele durante e após a II Guerra Mundial, pois esses foram grandes marcos e bastante influentes para o seu desenvolvimento (Meister, 1999, p.147).

Pretende-se, com essa abordagem, discutir o surgimento da ergonomia nos EUA, dividindo seu desenvolvimento nas duas épocas supracitadas. Pretende-se apresentar também alguns nomes importantes para o desenvolvimento da ergonomia nesse país.

\section{Primeiros passos: a ergonomia no período anterior às guerras mundiais}

De acordo com Meister (1999, p.147), os testes de adequação da máquina ao homem realizados no período anterior às Guerras eram basicamente empíricos, ou seja, testes estritamente relacionados à tentativa e ao erro. Ainda segundo esse autor, houve um pequeno esforço durante a Guerra Civil Americana (1861-1865), por parte do U.S. Patent Office, para que os uniformes e armas produzidos em massa servissem aos soldados que participariam desse combate.

Ainda no século XIX, surgiram os estudos mais sistemáticos sobre o trabalho, os quais iriam decorrer no denominado taylorismo (Frederick Winslow Taylor), o novo conceito de administração científica, onde se considerava que o trabalho deveria ser sistematicamente observado e que, para cada tarefa, fosse desenvolvido um método correto para executá-la, de forma que esta fosse realizada num determinado tempo e utilizando as ferramentas corretas. De acordo com Iida (2005, p.8), "Os trabalhadores deveriam ser controlados, medindo-se a produtividade de cada um e pagando-se incentivos salariais àqueles mais produtivos". O trabalho dos funcionários era observado e cronometrado, percebendo-se assim que as atividades deveriam ser realizadas em tempos-padrão sem levar em consideração as características individuais de cada trabalhador. 
Pode-se destacar ainda nesse período anterior à Primeira e Segunda Guerras Mundiais que os estudos realizados pelo casal Liliam E. e Frank G. Gilbreth decorreram em pesquisas a respeito da fadiga e fundaram uma empresa de consultoria bastante respeitada em meio aos profissionais da área, a Frank B. Gilbreth, Inc. - 1911. O trabalho desse casal pode ser considerado um dos precursores do que viria a se chamar posteriormente de human factors (Sanders; McCormick, 1993).

Frank G. Gilbreth começou a desenvolver observações sobre movimentos aos 27 anos, quando trabalhava como superintendente em uma empresa de construção. Já Liliam E. Gilbreth se dedicou à psicologia, ajudando seu marido nos estudos sobre fadiga (Martins, 2004, p.4).

O casal se dedicou aos estudos dos movimentos, ao contrário de Taylor, que trabalhava com a questão do tempo. Eles desenvolveram técnicas para evitar o desperdício de tempo e movimento, assim como criaram padrões, racionalizando as tarefas de produção com intuito de aumentar a produtividade. Também preocupados com a fadiga eles propuseram o redesenho do ambiente de trabalho, a redução de horas de trabalho e a implantação ou aumento de dias de descanso remunerado. Os Gilbreth realizaram uma análise nas equipes de cirurgiões de hospitais, e seu trabalho resultou em um procedimento utilizado ainda hoje: "um cirurgião obtém um instrumento pedindo por ele e estendendo a mão para uma enfermeira, que coloca o instrumento na posição correta" (Sanders; McCormick, 1993, p.7). Eles concluíram que na antiga técnica os cirurgiões passavam muito tempo procurando pelos instrumentos.

Apesar desse primeiro interesse no estudo da relação entre o homem e o seu trabalho percebe-se aqui que a ideia de adaptar equipamentos e procedimentos às pessoas não era completamente explorada (Sanders; McCormick, 1993, p.7). Percebe-se também que o desenvolvimento da ergonomia era associado às questões industriais, colocando a produtividade em primeiro lugar e esquecendo-se das individualidades humanas. 


\section{O desenvolvimento da ergonomia a partir da Primeira Grande Guerra Mundial}

Durante a Primeira Grande Guerra Mundial a ergonomia desenvolveu-se principalmente devido à produção de novos armamentos, que, em alguns casos, eram muito sofisticados para os usuários. Isso fez com que surgisse o interesse em estudar a questão do relacionamento do homem com seus instrumentos de trabalho (Meister, 1999). Assim, percebeu-se que, mesmo havendo um desenvolvimento do estudo da relação do homem com seu trabalho, a procura de soluções ainda era realizada de maneira a se achar o melhor indivíduo para se adaptar ao trabalho. De acordo com esse mesmo autor, ainda não foi nesse momento que a human factors engineering se desenvolveu, pois os EUA tiveram um menor envolvimento nesse combate, apenas 18 meses, mas parece ser evidente que esses primeiros estudos foram importantes para o desenvolvimento dessa disciplina.

Nas décadas de 1920 e 1930 uma série de experimentos foram realizados por Elton Mayo e seus colegas na fábrica Hawthorne da Western Electric Company. Esses estudos são de interesse mais por sua influência, que foi chamar a atenção para os fatores sociais no trabalho, do que para seus resultados. Os investigadores começaram a examinar os efeitos de iluminação, pausas de descanso e menos horas na produtividade e fadiga.

Um experimento frequentemente citado se refere a uma tarefa de montagem de relés. Os pesquisadores começaram manipulando os níveis de iluminação para observar o efeito sobre a produção. Inesperadamente, constatou-se que a produção aumentou - mesmo quando a iluminação foi reduzida. Esse resultado é o básico da crença no "efeito Hawthorne" e é usado como evidência para a importância social, em vez de fatores físicos na determinação do desempenho do trabalhador.

Os experimentos de Hawthorne ganharam seu lugar na história, inaugurando uma nova era da pesquisa em "Relações Humanas" no local de trabalho e chamando a atenção para a importância dos 
determinantes sociais e pessoais de comportamento do trabalhador. No entanto, as experiências próprias e sua interpretação sempre foram controversas.

Em 1934, a força aérea dos Estados Unidos foi tomada abruptamente da missão de servir de correio aéreo. O corpo de pilotos treinados para voarem olhando para o solo não podia fazer o serviço adequadamente, pois não estava habituado a voar dessa maneira. Após 10 pilotos caírem, o corpo de pilotos virou-se para uma invenção denominada "Link trainer".

Com esse simulador, um cadete aviador podia ser treinado em instrumentação de voo sem as complicações introduzidas por um avião de verdade.

O primeiro "Link trainer" foi construído por Edwin Link em 1920, no porão da casa de seu pai quando este, determinado a aprender a voar, não possuía fundos para as horas de voo requeridas.

Durante a Segunda Grande Guerra Mundial o aparelho foi utilizado para treinar mais de 500.000 cadetes. Atualmente, simuladores são produzidos para pilotos, astronautas e operadores de submarino. Um sofisticado módulo controlado por computadores ajudou o homem ir à Lua.

\section{O período da Segunda Grande Guerra Mundial}

Com o começo da Segunda Grande Guerra Mundial todos os esforços na área tecnológica foram destinados à produção de instrumentos bélicos relativamente complexos, equipamentos que exigiam habilidade do operador em ambientes desfavoráveis, onde os acidentes e erros eram frequentes e por vezes tinham consequências fatais (Iida, 12005). Essas condições fizeram com que fossem redobrados os esforços para pesquisar formas de adaptar os instrumentos bélicos às características e capacidades dos operadores, a fim de reduzir a fadiga e os acidentes. Ao final da Guerra as descobertas feitas durante esse período foram aplicadas à vida civil para melhorar as condições de trabalho e a produtividade da população em 
geral. De acordo com Iida (2005), os profissionais da área relatavam que nesse período suas pesquisas eram encaradas com ceticismo e dúvida, e que os pesquisadores dessa área eram geralmente ridicularizados. Foi só após o Departamento de Defesa dos EUA apoiar as pesquisas em ergonomia que essa situação mudou. Foi nesse contexto que se desenvolveu a ergonomia nos Estados Unidos.

Foi somente durante a Segunda Grande Guerra Mundial que ficou claro que nem mesmo com a melhor seleção, e o melhor treinamento, a operação de alguns comandos ainda excedia as capacidades dos operadores (Sanders; McCormick, 1993). Possivelmente esse foi o momento em que se percebeu a necessidade de adaptar os equipamentos às pessoas. Durante esse período houve o estabelecimento de laboratórios de psicologia nas forças armadas americanas a fim de diagnosticar possíveis problemas psicológicos em oficiais da aeronáutica após a guerra (Meister, 1999, p.172).

As pesquisas ergonômicas no período de guerra encorajaram a formação do "psychology branch of aero medical laboratory" na base aérea Wright-Patterson em Dayton, Ohio, em maio de 1945, sob a liderança do psicólogo e tenente-coronel da força aérea dos EUA Paul M. Fitts. Entre as várias contribuições do grupo liderado por Fitts destacam-se os fundamentos da psicologia da aviação, com os estudos detalhados dos erros dos pilotos (Fitts; Jones, 1947). Elaborou o que ficou conhecida como a "lei de Fitts", cujo enunciado é: "o tempo para acertar um alvo está em função da distância e do tamanho do alvo."

Sua teoria encontrou aplicação também no campo civil com o advento dos computadores com interfaces gráficas de usuário (GUI graphic user interface), utilizando-a para o sistema de controle de posicionamento de cursores, possibilitando um manejo mais adequado do mouse, por exemplo.

Além disso, suas contribuições incluíram uma das mais recentes e muito influentes taxonomias para alocação de funções entre humanos e máquinas, e validação de características de controle manual humano. Destacam-se também os trabalhos desse grupo no comportamento do movimento dos olhos dos pilotos e aspectos 
ergonômicos do tráfego aéreo (Tsang; Vidulich, 2003, p.3). Fitts é de longe reconhecido como um dos precursores da psicologia da aviação e também da moderna ergonomia.

\section{Discussão e considerações finais}

As raízes da ergonomia nos Estados Unidos da América se concentraram nos aspectos produtivos, como o aumento da produção e do lucro. Porém, ao longo do tempo, percebeu-se a importância de se considerar as condições individuais do homem.

Durante os esforços de guerra para reduzir o número de baixas e aumentar a eficiência dos combates, os equipamentos desenvolvidos por Link e os estudos de Fitts foram cruciais para o desenvolvimento de formas mais seguras e eficientes de pilotar aeronaves. Sabe-se que o apoio aéreo foi fundamental para o sucesso do desembarque na Normandia (dia D) e a vitória dos aliados na Segunda Grande Guerra Mundial, então não é exagero afirmar que a ergonomia teve grande peso na definição do conflito.

Gillespie (1991) oferece uma visão fascinante sobre o contexto histórico das experiências de Hawthorne e as motivações dos atores principais, nomeadamente Elton Mayo. Este último ficou impressionado com os avanços na eficiência industrial, na engenharia e com a introdução de métodos de produção em massa, além das obras de Sigmund Freud, em especial os escritos sobre a "Psicopatologia da vida cotidiana”, e formou a opinião de que os trabalhadores não cooperativos estavam sofrendo de um tipo de psicopatologia favorável ao tratamento.

Essas ideias foram atrás de seu interesse em relações humanas no trabalho e sua crença de que a próxima onda de aumentos de produtividade seria alcançada, através de técnicas psicológicas, em vez de incentivos econômicos, para motivar os trabalhadores. A possibilidade de que a produtividade pode ser aumentada através da manipulação do ambiente social em vez de pagar aos trabalhadores mais dinheiro era obviamente atraente para a gestão Western 
Electric, embora ainda há poucas evidências de que os experimentos de Hawthorne forneceram qualquer apoio a essas reivindicações.

Uma das consequências imediatas das experiências de Mayo foi a introdução de um serviço de aconselhamento de pessoal na fábrica. Em 1950, a Western Electric possuía 20.000 trabalhadores empregados no Hawthorne e tinha um departamento de aconselhamento de cerca de 40 pessoas que entrevistou mais da metade dos operários durante um período de dez anos. O método utilizado foi não diretivo, confidencial e neutro, similar em algumas maneiras para o cliente centrado psicoterapia de Carl Rogers, que data da mesma época.

Os custos e benefícios do serviço não parecem ter sido avaliados, apesar de Wilensky e Wilensky (1951) concluírem que o aconselhamento pareceu ser eficaz como meio complementar de exercer o controle de gestão sobre os trabalhadores, drenando o ressentimento e a amargura que, de outra forma, ganhariam expressão através do sindicalismo militante.

\section{Referências bibliográficas}

FITTS, P. M.; JONES, R. E. Analysis of factors contributing to 460 "pilot error" experiences in operating aircraft controls. Memorandum Report TSEAA-694-12, Aero Medical Laboratory, Air Material Command, Wright-Patterson Air Force Base, Dayton, Ohio, July 1, 1947.

IIDA, I. Ergonomia: projeto e produção. $2^{\mathrm{a}}$ ed. São Paulo: Edgard Blücher, 2005.

LAVILLE, A. Ergonomia. Trad.: Márcia Maria Neves Teixeira. São Paulo: Editora Pedagógica e Universitária Ltda., 1977.

MARTINS, E. M. MTM como ferramenta para redução de custos: o taylorismo aplicado com sucesso nas empresas de hoje. 2004. Trabalho acadêmico - Universidade Federal de Santa Catarina, 2004.

MEISTER, D. The history of human factors and ergonimics. Mahwah: Lawrence Erlbaum Associates, Inc., Publishers, 1991.

SANDERS, M. S., MCCORMICK, E. J. Human factors in engineering and

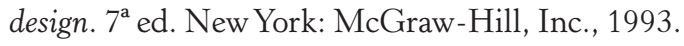

TSANG, P. S.; VIDULICH, M. A. Principles and practice of aviation psychology (Human Factors in Transportation). Lawreance Erlbaum Associates, Inc. Publishers, 2003. 


\title{
9 \\ ERgonomia na AmÉRICA Latina: INICIATIVAS, ESTABELECIMENTO E CONSOLIDAÇÃO
}

\author{
Carlos Eduardo Lins Onofre \\ Ana Cláudia Scarpim \\ Cláudio Vidrih Ferreira \\ José Carlos Plácido da Silva \\ Luis Carlos Paschoarelli
}

\section{Introdução}

Os princípios da ergonomia ainda são controversos, e algumas reflexões levam a crer que ela esteja associada aos primórdios da manipulação de instrumentos (pedra lascada), mas não é possível negar que a oficialização da ergonomia tem como marco inicial o dia 12 de julho de 1949, quando "...reuniu-se pela primeira vez, na Inglaterra, um grupo de cientistas e pesquisadores interessados em discutir e formalizar a existência desse novo ramo de aplicação interdisciplinar da ciência" (Meister, 1991). Assim, em 1949, foi fundada a Ergonomics Research Society, conhecida apenas por Ergonomics Society.

A partir daí, com estudos de pesquisadores, engenheiros e médicos do trabalho, a ergonomia evoluiu com as primeiras pesquisas realizadas enfocando o homem e suas atividades profissionais.

Os reflexos do surgimento da ergonomia no mundo foram sentidos gradativamente nas mais diferentes partes do mundo, incorporando melhorias e trazendo benefícios à qualidade de vida do trabalhador. 
Na América Latina, mesmo sessenta anos depois do surgimento da ergonomia, os estudos na área ainda parecem estar numa fase de consolidação.

\section{Ergonomia na América Latina}

O princípio dos estudos da ergonomia na América Latina se deu na década de 1960, com pesquisas desenvolvidas na Escola Politécnica da Universidade de São Paulo, no Brasil - país que tem se mostrado o mais consolidado do bloco no desenvolvimento da disciplina (Soares, 2006). Entretanto, outros países latinos-americanos também têm contribuído, de forma diferenciada, com a evolução da ergonomia, com destaque também para a Argentina e o Chile.

\section{Argentina}

Na Argentina a ergonomia é uma área do conhecimento que apresenta-se ainda negligenciada, apesar de haver certo interesse da comunidade acadêmica em vê-la desenvolvida (Soares, 2006). Isso se deve ao fato de que as questões sobre a melhoria da qualidade de vida no trabalho foram relegadas às políticas do país, mais focadas na reestruturação industrial, privatização e controle da inflação (Hiba, 1991).

De acordo com a Asociación de Ergonomía Argentina (Adea, 2010), historicamente, a ergonomia na Argentina apresentou três períodos bem definidos. O primeiro deles, ocorrido nas décadas de 1950-1960, teve o interesse ergonômico voltado para a saúde dos trabalhadores e aspectos fisiológicos do trabalho humano, destacando-se como marco da época a criação da Sociedade Argentina de Ergonomia. O objetivo dessa organização era realizar estudos, investigação e ensino sobre questões relacionadas com o trabalho humano; e por 15 anos estruturou e organizou os primeiros congressos e conseguiu publicar uma revista, até que em 1975 deixa de ser atuante e desaparece. 
O segundo período dá-se na década de 1970, quando o interesse dos estudos ergonômicos passa a ser focado na antropometria e nas interações entre o homem e a máquina, bem como na criação de laboratórios de ergonomia aplicada. Nesse período, foram realizados estudos em empresas e vários eventos sobre o assunto, além de serem firmadas muitas parcerias acadêmicas com instituições europeias para a formação de ergonomistas.

O terceiro e último período ocorreu a partir da década de 1980, quando foram realizadas ações específicas, como a Renalergo, ou "Reuniões Nacionais de Laboratórios de Ergonomia", que se sucederam a cada quatro anos até 1995, quando foi realizada a última reunião em Córdoba. Esse período foi marcado pela cooperação entre a Argentina, a Alemanha e a França, para formação acadêmica de profissionais da área, e efetivou-se quando 27 engenheiros e médicos foram treinados na Alemanha e criaram o laboratório denominado REFA, com sede na Universidade Tecnológica Nacional (NTU), que começou a funcionar em 1982, garantindo a pesquisa e o ensino da ergonomia. No fim dos anos 1990 foi desativado por não ter uma clara política de apoio.

Entre 1986 e 1995, como evidência da cooperação científica entre a França e a Argentina, vários ergonomistas franceses e pesquisadores de outras áreas, tais como Wisner, Laville, Queinnec, Dessors e Jaillet, vieram à Argentina e deixaram suas contribuições.

Conforme Adea (2010), em 1995, na cidade de Córdoba e com apoio da Renalergo, foi criada, pela segunda vez, a Asociación de Ergonomía Argentina, que durou três anos; e em 2002 se cria, pela terceira vez, em Buenos Aires, a Asociación de Ergonomía Argentina (Adea). Em pouco tempo é reconhecida pelo IEA e se torna cofundadora da Ulaergo.

Mas somente em 2003 o governo argentino reconhece legalmente a aplicação dos estudos da ergonomia, fazendo publicar no Diário Oficial da Argentina a Resolução n 295/03 do Ministério do Trabalho, Emprego e Segurança Social composta de 5 anexos, sendo o primeiro intitulado "Ergonomia". É a primeira vez que os ergonomistas argentinos se tornam visíveis e necessários perante a sociedade. 


\section{Chile}

De acordo com Del Pino (2010), a ergonomia no Chile começa com as iniciativas do médico fisiologista Hugo Donoso Puelma, que trabalhava com atividades físicas e desportivas. Esse médico, desde o fim da década de 1960, realizava pesquisas e publicava seus resultados no periódico científico Ergonomics. A partir da década de 1970 são reconhecidos também os trabalhos de Elias Apud, na Universidade de Concepción, sobre os processos de trabalho na silvicultura (Del Pino, 2010); e particularmente no ano de 1972, por iniciativa de Ennio Vivaldi, foi criado o primeiro laboratório de ergonomia do Chile, dedicado exclusivamente à docência, investigação, difusão e assistência técnica dessa disciplina. De acordo com Soares (2006), datam dessa década estudos ergonômicos efetuados por vários laboratórios e instituições. Nesse período, os estudos da ergonomia também estavam presentes em cursos de graduação e pós-graduação naquele país.

Também de acordo com Del Pino (2010), a partir de 1996 se iniciou uma nova tentativa de criar a Sociedade Chilena de Ergonomia, a qual, finalmente, foi instalada em 30 de outubro de 1998. Sua personalidade jurídica foi decretada em 25 de janeiro de 2000 pelo Ministério de Justiça Chileno. O Chile contou ainda com a Comissão Nacional de Ergonomia associada ao governo, além da Fundação Científica e Tecnológica da Associação Chilena de Segurança, a qual edita o periódico chileno "Ciencia y Trabajo", contemplando o tema ergonomia.

\section{Colômbia}

A Colômbia iniciou-se na ergonomia a partir de programa de prevenções de riscos no trabalho, por meio de serviços de companhias de consultoria (Soares, 2006).

Segundo informações da Sociedad Colombiana de Ergonomía (SCE, 2010), os primeiros higienistas industriais chegaram à Co- 
lômbia na década de 1960, com profissionais formados no exterior. Particularmente, em 1967, a Universidade de Cauca recebeu a denominada missão sueca que introduziu um programa de pesquisa em antropometria. Também nesse ano foi publicado o primeiro livro no país relacionado com a ergonomia, de autoria de Jairo Flórez (SCE 2010). Em 1969, em Bogotá, realizou-se o congresso ibero-americano de segurança, sendo que a partir da década de 1970 a Colômbia já passa a ter certa autonomia nos estudos de ergonomia, desenvolvidos em suas próprias universidades (SCE, 2010).

De acordo com a SCE (2010), na década de 1970, foi introduzida a disciplina de ergonomia nos cursos de Engenharia Industrial da Universidade de Antióquia, devido ao trabalho do engenheiro espanhol Jorge Forcadas, fundador do curso e autor do livro Curso sobre Ergonomia (1978), dando início à formação em saúde ocupacional.

Na década de 1980, consoante informação da SCE (2010), foram publicados livros de ergonomia de Jairo Estrada. Também na década de 1980 foi fundada a Associação Colombiana de Ergonomia, que infelizmente deixou de existir prematuramente.

Conforme destacado em Soares (2006), o ano de 1996 foi marcado pela realização do Primeiro Congresso de Ergonomia da Colômbia, no qual ocorreu o ressurgimento da Sociedad Colombiana de Ergonomía - SCE.

\section{México}

No México, a primeira associação de ergonomia surgiu na década de 1970, entretanto, as suas ações, como a realização de congressos constantes e consultoria em normas, tornaram-se mais eficientes somente a partir de 1997, quando a Sociedad de Ergonomistas de Mexico (Semac) foi refundada.

A prática de ergonomia no México surgiu a partir da década de 1990, com a abertura da carreira de desenho industrial na Universidade Ibero-americana. Posteriormente, outras escolas passaram a 
oferecer cursos de ergonomia. Mas, no campo acadêmico, a ergonomia está presente em vários cursos de graduação, principalmente fomentados pela área de desenho industrial (Soares, 2006).

\section{Panamá}

No Panamá, apesar da enorme influência da antiga zona do canal e de seu enclave colonial na vida dos panamenhos, os primeiros critérios e princípios relacionados à ergonomia foram aplicados de modo empírico na área agrícola. Mas o início dos estudos ergonômicos está intimamente associado à chegada do médico Francisco M. Diaz Mérida, em julho de 1977.

Embora em 1978 tenha sido publicado o primeiro trabalho investigativo relacionado com a saúde e segurança dos trabalhadores (o fator humano na prevenção de riscos na agricultura), foi na década de 1980 que surgiu a denominada época de ouro da saúde ocupacional do Panamá.

Nessa década, foram recrutados os primeiros sete técnicos em saúde ocupacional panamenho e capacitados em diferentes centros e distintos períodos de tempo, predominando a influência da escola mexicana.

Em 24 de agosto de 1983, Harry Chandler foi formalmente nomeado como "ergonomista" do programa de saúde ocupacional da caixa de seguro social. Na ocasião, praticamente não havia ferramentas e dispositivos específicos de trabalho, além de inexistirem outros profissionais, junto com os quais seria possível discutir os assuntos pertinentes à área. $\mathrm{O}$ primeiro contato com outro pesquisador só surgiu seis anos depois, com a vinda da ergonomista norteamericana Jennifer Gordon, para atuar na divisão de segurança industrial da zona do canal. Além disso, não se pode esquecer a contribuição efetiva da professora Mariana McPherson, da Universidade Tecnológica do Panamá, que na década de 1980 ministrou aulas nessa área e manteve estreita e constante a atividade docente com o programa de saúde ocupacional dessa universidade. 


\section{Peru}

O Peru ainda é iniciante em educação formal na área de ergonomia, assim como a questão da normatização. Somente em 2008, objetivando a proteção do menor e a segurança e saúde no trabalho, o governo peruano aprovou uma norma básica de ergonomia. Por outro lado, a Sociedad Peruana de Ergonomía (Sopergo) mantém uma atividade envolvendo encontros e cursos no país (Soares, 2006). O $1^{\circ}$ Congresso Peruano e o $1^{\circ}$ Congresso Internacional de Ergonomia foram organizados pela Sopergo e tiveram como tema central "desenvolver a ergonomia no país", realizados em novembro de 2009.

\section{A articulação da América Latina}

De acordo com Lima (2008), os países da América Latina encontram-se em situações de economia distintas entre si, porém, olhando-se num panorama mundial, pode-se dizer que tratam-se de nações "em desenvolvimento" ou "emergentes". Além disso, são países que geralmente estão à sombra de nações consideradas desenvolvidas, inclusive em termos de tecnologia e produção acadêmica. Essa condição se estende a muitas áreas e podem ser observados seus rebatimentos no âmbito do desenvolvimento tecnológico.

No que diz respeito à articulação da ergonomia na América Latina, de acordo com Soares (2006), destaca-se a Ulaergo (União Latino-americana de Ergonomia), a qual conta com representantes do Brasil, da Colômbia e do Chile. Essa entidade foi constituída na Colômbia em novembro de 2001 (e criada formalmente em 2002).

Essa reunião, consoante Soares (2006), começou com um retrospecto dos esforços de unir as associações latino-americanas desde o Congresso da Associação Brasileira de Ergonomia (Abergo) de 1987.

No acordo destacam-se as metas de criação de uma revista latino-americana de ergonomia e formação de uma comissão de elaboração de uma grade curricular mínima em ergonomia, para 
aplicação acadêmica no bloco (Ulaergo, 2001). Além disso, devese considerar que essas ações poderão trazer grandes vantagens, já que "...no futuro, a Ulaergo pode tornar-se um catalisador de mudanças na ergonomia latino-americana, amparando a formulação de políticas comuns entre os países membros, o que por sua vez pode estimular o desenvolvimento $e$ atender à diversidade entre os povos" (Soares, 2006, p.6).

Até março de 2010, constavam no site eletrônico da Ulaergo (http://www.ulaergo.net) nove países associados: Argentina, com a Asociación de Ergonomía Argentina - Adea; Bolívia, com a Sobolergo; Brasil, com a Abergo; Chile, com a Sociedad Chilena de Ergonomía (Sochergo); Colômbia, com a SCE; Cuba, com o correspondente Ricardo Montero; México, com a Semac; Peru, com a Sopergo; e Venezuela, com a Unión Venezoelana de Investigadores en Ergonomía y Salud Ocupacional (Uvierso).

A Ulaergo é atualmente a entidade de articulação internacional para a disciplina no bloco, tanto que o número de ergonomistas latino-americanos em conferências internacionais promovidas pela IEA tem crescido consideravelmente, conforme indicado por Soares (2006).

Nesse cenário, pode-se constatar que a maioria das nações do bloco ainda carece de articulação internacional, no sentido da divulgação de seus estudos e exercícios da ergonomia.

\section{Discussão e considerações finais}

De forma geral, observa-se que na América Latina o interesse pela ergonomia é recente, ficando, na maioria das vezes, confinada na academia ou em cursos específicos, não se desenvolvendo plenamente na área industrial.

Nesse sentido, é de interesse científico questionar o motivo pelo qual a ergonomia encontra-se confinada nos muros acadêmicos, com poucos investimentos e pesquisas de aplicação prática que possam trazer significativos reflexos nos setores produtivos. 
É primordial que se mobilize esforços no sentido da busca de políticas adequadas à realidade da América Latina, de tal sorte que possa se prever o estabelecimento de um processo contínuo de industrialização, em consonância com as condições ambientais e culturais dos países desse bloco latino.

Nesse contexto, não seria exagero vislumbrar um novo horizonte para a ergonomia, que a curto ou médio prazo contribuiria com produções acadêmicas e práticas, destacando a importância dos países membros da Ulaergo no cenário mundial.

\section{Referências bibliográficas}

ASOCIACIÓN CHILENA DE SEGURIDAD. Revista Ciencia y Trabajo. Fundación Científica y Tecnológica. Disponível em http://www. cienciaytrabajo.cl/. Acessado em 23/3/2010.

ASOCIACIÓN DE ERGONOMÍA ARGENTINA - ADEA (2010).

Disponível em http://adeargentina.org.ar/historia/. Acessado em 22/3/2010.

DEL PINO, M. La Ergonomía em Chile. Disponível em marcelodelpino. iespana.es/.../apunte $\% 201 \% 20 \% 20 \mathrm{a} \% 20$ ergonomia.doc. Acessado em 22/3/2010.

HIBA, J. C. Ergonomics training in Argentina: Origins, current situation and proposal for overcoming a difficult present, 1991. Disponível em http://peruergo.blogspot.com/2010/03/historia-de-la-ergonomia_01. html. Acessado em 24/3/2010.

IIDA, I. Ergonomia: projeto e produção. São Paulo: Edgard Blücher, 2005. LIMA, M. M. T. Reflexões sobre o desenvolvimento tecnológico na América Latina: desafio da adequação. Revista Espaço Acadêmico. 86: 2008. 6p. Disponível em http://www.espacoacademico.com.br/086/86lima.htm. Acessado em 24/3/2010.

MEISTER, D. The history of human factors and ergonimics. Mahwah: Lawrence Erlbaum Associates, Inc., Publishers, 1991.

SOARES, M. M. Ergonomics in Latin America: Background, trends and challenges. Applied Ergonomics. 37 (04): 555-561, 2006.

SOCIEDAD COLOMBIANA DE ERGONOMÍA - SCE. Disponível em http://sociedadcolombianadeergonomia.com/index. php?pag=ergonomia. Acessado em 25/3/2010. 
ULAERGO. Declaración de Santiago de Chile. S/d. Disponível em http:// www.ulaergo.net/historia.php. Acessado em 23/3/2010.

Reunión Constitutiva: Unión Latinoamericana de Ergonomía ULAERGO. Disponível em http://www.ulaergo.net/historia.php. Acessado em 23/3/2010.

UNESCO. Latin America and the Carribean. Disponível em http://www. unesco.org/new/en/unesco/worldwide/unesco-regions/latin-americaand-the-caribbean/. Acessado em 24/3/2010.

UNITED NATIONS. The world. Disponível em http://www.un.org/ Depts/Cartographic/map/profile/world.pdf. Acessado em 25/3/2010. 


\title{
10 \\ TRAJETÓRIA DA ERGONOMIA NO BRASIL: ASPECTOS EXPRESSIVOS DA APLICAÇÃO EM DESIGN
}

\author{
Cristina do Carmo Lucio \\ Silvana Aparecida Alves \\ Bruno Montanari Razza \\ José Carlos Plácido da Silva \\ Luis Carlos Paschoarelli
}

\section{Introdução}

Da definição do conceito ergonomia por Kenneth Frank Hywel Murrell, em 1949, até o início dos primeiros estudos brasileiros nessa área, passaram-se mais de 20 anos. Foi na década de 1970 que, influenciadas pelo pesquisador francês Alain Wisner, se iniciaram as primeiras abordagens ergonômicas, o que justifica, até os dias atuais, o fato de muitos estudos ergonômicos no país seguirem a abordagem francesa do Analyse Ergonomic Du Travail - AET (Scott, 2009). Mas foi na década de 1990, com base em um método proposto pelas professoras Anamaria de Moraes e Cláudia Mont'Alvão, que novos estudos ergonômicos surgiram, ganhando força principalmente devido à descrição clara dos muitos obstáculos que surgem em um estudo ergonômico (Scott, 2009). Essa mesma autora defende que, apesar das diferenças nos termos utilizados, ambos os estudos são descritivos e propõem um diagnóstico bem detalhado, mas não levam necessariamente à aplicação e avaliação futura de melhoria do trabalho, invocando a experiência do especialista em ergonomia, e não, necessariamente, aos trabalhadores e gestores. Moraes e Soares (1989) corroboram ao informar que nessa 
época não se aplicavam experimentos em laboratório, apenas eram propostas modificações baseadas na literatura estrangeira vigente. Fato concreto é que, segundo Soares (2005), a ergonomia brasileira surgiu da difusão da ergonomia em âmbito internacional e desde então ocupa um relativo destaque nesse cenário, particularmente no âmbito latino-americano.

Moraes e Soares (1989) afirmam que as primeiras vertentes de implantação da ergonomia no Brasil ocorreram juntamente às engenharias e ao design, sem aplicação experimental, conforme citado. Na USP de Ribeirão Preto e na FGV do Rio de janeiro, duas novas abordagens passaram a ser aplicadas com base no enfoque da psicologia, sendo respectivamente o desenvolvimento de pesquisas experimentais sobre o comportamento de motoristas e trabalhos com ênfase nas análises sociotécnicas.

Somente a partir do surgimento dos livros de Chapanis em 1962 e 1972, intitulados respectivamente Research Techniques in Human Engineering e A Engenharia e o Relacionamento Homem-Máquina, e de Meister em 1971 e 1985, intitulados respectivamente Human Factors: Theory and Practice e Behavioral Analysis and Measurement Methods, é que uma nova abordagem metodológica com ênfase na observação sistemática do trabalho, com o desenvolvimento da análise da tarefa, medições do ambiente e levantamentos antropométricos, passaram a fazer parte do escopo do ergonomista brasileiro (Soares, 2005). Segundo o autor, a literatura francesa da década de 1980, com destaque para os livros de Montmollin, Sperandio e Wisner, e a literatura sobre a interação homem-computador acrescentaram ferramentas e métodos de intervenção ergonômica no país. É possível afirmar assim que a origem da ergonomia no Brasil possui duas abordagens metodológicas: a de origem francesa, inicial, e a de origem anglo-saxônica, que, segundo Soares (2005), não são contraditórias, mas, sim, complementares.

Um fator que contribuiu para a existência da influência francesa foi o intercâmbio realizado por pesquisadores brasileiros que foram para a França cursar mestrado e doutorado sob a orientação do professor Alain Wisner ou do professor Maurice de Montmollin. Ao retornarem ao Brasil, ingressaram em cursos de especialização em 
ergonomia, pelas várias instituições universitárias que começaram a formar especialistas na área, passando assim a transmitir seus conhecimentos adquiridos.

\section{Pioneiros e contribuições iniciais}

\section{Primeiros estudos relacionados}

Apesar de o conhecimento ergonômico ter sido disseminado a partir da segunda metade do século XX, especificamente a partir da década de 1960 (Soares, 2006) foi verificado um estudo sobre medições antropométricas na literatura científica, remontando do fim do século XIX. Esse estudo, citado por Baten et al. (2009), trata de medições antropométricas com 6.771 prisioneiros do sexo masculino da cadeia da cidade do Rio de Janeiro, para o qual foram coletadas informações de altura, origem, ocupação, local de nascimento, idade e cor da pele. O estudo apresenta alguns gráficos com dados de altura de brasileiros nascidos a partir de 1810, além de discutir questões relacionadas à antropometria e questões relacionadas ao trabalho, porém estas últimas de cunho socioeconômico. Um dado curioso exposto por esse estudo é que anteriormente a 1879 a altura era medida em "pés" portugueses, e somente a partir de então em metros.

\section{Pioneiros}

Após tomar o depoimento dos precursores brasileiros da ergonomia, Moraes e Soares (1989) e Moraes (1999) concluíram que houve seis principais vertentes para a difusão da ergonomia no país.

A primeira vertente ocorreu na década de 1960, no curso de Engenharia de Produção da Escola Politécnica da USP, com o professor Sérgio Penna Kehl, através da abordagem "O Produto e o Homem".

A segunda vertente, iniciada no início da década de 1970, ocorreu com a introdução do ensino de ergonomia no curso de Engenharia de Produção, do Programa de Pós-graduação em Engenharia da 
UFRJ. Contou com o professor Itiro Iida como docente e constituiuse num centro de disseminação de conhecimentos da ergonomia, produzindo várias teses e dissertações nessa área de conhecimento.

A terceira vertente ocorreu em 1976, com a introdução do ensino de ergonomia no curso de Desenho Industrial da Escola Superior de Desenho Industrial da UERJ, com o professor Karl Heinz Bergmiller, lecionando ergonomia para o desenvolvimento de projetos de produtos, seguindo o modelo de Tomás Maldonado da Escola de Ulm.

A quarta vertente, na década de 1970, foi identificada através de estudos relacionados à psicologia ergonômica, com ênfase na percepção visual aplicada no estudo do trânsito, no curso de Psicologia da USP de Ribeirão Preto, no qual se implantou uma linha de pesquisa, coordenada pelos professores Reinier Rozestraten e Paul Stephaneck.

A quinta vertente, na década de 1970, compreendeu a área de Psicologia do Instituto Superior de Estudos e Pesquisas Psicossociais da Fundação Getulio Vargas, no Rio de Janeiro, o qual foi coordenado pelo professor Franco Lo Presti Seminério e promoveu, em 1974, o $1^{\circ}$ Seminário Brasileiro de Ergonomia, marco fundamental na história da ergonomia brasileira. Também coube a esse instituto a implantação do primeiro curso de especialização em ergonomia no Brasil, no ano de 1975.

A sexta vertente foi marcada, ainda nos anos 1970, pela visita do professor Alain Wisner do Conservatoire National des Arts et Métiers de Paris, cuja vinda se deu graças à iniciativa do professor Franco Lo Presti Seminério. O professor Wisner tanto incentivou a ergonomia brasileira quanto orientou um dos primeiros trabalhos de ergonomia da Fundação Getulio Vargas, cujo tema era a plantação de cana-de-açúcar na área rural da cidade de Campos, no Rio de Janeiro. Também incentivou vários brasileiros à pós-graduação em ergonomia na sua instituição de origem, já na década de 1980. Os egressos dessa instituição francesa distribuíram-se por vários Estados e cidades, como Rio de Janeiro, São Paulo, Florianópolis, Belo Horizonte e Brasília, e hoje são responsáveis pelo desenvolvimento de pesquisas e programas de pós-graduação. 


\section{Primeiros trabalhos técnicos e científicos}

O primeiro livro de ergonomia escrito por autor brasileiro foi publicado em 1973, intitulado "Ergonomia: notas de classe", pelo professor Itiro Iida e por Henri A. J. Wierzbicki (Ferreira; Donatelli, 2001). Em 1978, Roberto Verdussen publica o livro intitulado "Ergonomia: a racionalização humanizada do trabalho". Anamaria de Moraes e Marcelo Márcio Soares publicaram, em 1989, a primeira edição do livro intitulado "Ergonomia no Brasil e no mundo: um quadro, uma fotografia”. No ano seguinte, Itiro Iida publicou a primeira edição do livro intitulado "Ergonomia: projeto e produção", que se constituiu em uma das obras brasileiras de ergonomia mais importantes e referenciadas no meio acadêmico.

Em 1994 Carlos Alberto Diniz publica a "Norma Regulamentadora 17 - Manual de utilização”. Em 1995 Neri dos Santos e Francisco Antonio Pereira Fialho publicam o "Manual de análise ergonômica no trabalho". Hudson de Araújo Couto lança "Ergonomia aplicada ao trabalho: o manual técnico da máquina humana”o volume I foi publicado em 1995 e o volume II em 1996. Anamaria de Moraes e Cláudia Mont'Alvão publicam "Ergonomia: conceitos e aplicações", em 1998.

No que se refere à publicação de livros sobre ergonomia no Brasil, Ferreira e Donatelli (2001) chamam a atenção para a pequena quantidade de livros publicados em língua portuguesa até o início da primeira década do século XXI. Até o ano de publicação do artigo dos referidos autores, havia apenas 18 livros editados em língua portuguesa, sendo que apenas 8 desses livros eram produzidos por autores brasileiros, os outros 10 eram traduções para o idioma português.

\section{Panorama das pesquisas em ergonomia}

No Brasil ainda não existe programa de pós-graduação stricto sensu em ergonomia, apesar de a Universidade Federal de Pernam- 
buco estar em vias de abrir o primeiro programa nessa área, no âmbito de um mestrado profissionalizante. Mas, de maneira geral, as instituições de ensino superior oferecem cursos de especialização em ergonomia, nível pós-graduação lato sensu, ao passo que nos Estados Unidos e em países europeus, por exemplo, já há cursos de mestrado e doutorado especificamente nessa área (Moraes; Soares, 1989).

Segundo Soares (2004), os cursos de especialização ministrados pelas universidades brasileiras estão distribuídos por vários Estados do país, conforme apresentado a seguir: Programa de Pósgraduação em Engenharia de Produção da Universidade Federal do Rio de Janeiro; Universidade de São Paulo; Núcleo de Ergonomia e Segurança do Trabalho da Faculdade de Engenharia da Universidade Federal de Juiz de Fora; Departamento de Design da Universidade Federal de Pernambuco; Departamento de Artes e Design da PUC/Rio de Janeiro; Instituto de Educação Continuada da PUC/Minas Gerais.

Atualmente apenas três cursos de pós-graduação stricto sensu em Design, reconhecidos pela Capes, apresentam linha de pesquisa em ergonomia, com destaque para a PUC/Rio de Janeiro, a Universidade Estadual Paulista e a Universidade Federal de Pernambuco.

Além desses cursos, vários grupos de pesquisa registrados no Diretório de Grupos do CNPq refletem o crescimento da pesquisa em ergonomia no país e ainda demonstram que a ergonomia está presente em várias áreas do conhecimento, tais como ciências sociais aplicadas, humanas, exatas, saúde, agrárias, entre outras (Soares, 2004).

Um levantamento realizado em 2010 no site do CNPq no diretório dos Grupos de Pesquisa no Brasil, utilizando a palavra-chave "ergonomia", identificou os grupos que realizam pesquisa nessa área. O levantamento foi realizado por áreas do conhecimento; ao acessar consultas em base corrente, nesta opção foram consultados os grupos que realizam pesquisa em ergonomia em todas as grandes áreas do conhecimento - ciências sociais aplicadas; ciências agrárias; ciências exatas e da terra; ciências biológicas; ciências da saúde; ciências humanas; engenharias; e linguística, letras e artes -, e, a partir dessa opção, definiu-se a área do grupo (Tabela 1). 
O levantamento feito por Soares em 2001 demonstrou que havia 101 grupos de pesquisa com estudos em ergonomia. O levantamento atual (Tabela 1) revela que houve um aumento na quantidade de grupos de pesquisa nos últimos anos, totalizando 165. Ressalta-se que os dados apresentados atualmente pelo diretório de grupos do CNPq foram computados no censo realizado em 2008 por esse órgão. Outro aspecto que deve ser destacado também refere-se à distribuição dos grupos de pesquisa por área do conhecimento e/ou área do grupo. Nesse caso, constata-se que a pesquisa com enfoque em ergonomia está presente em várias áreas do conhecimento humano.

Tabela 1 - Número de grupos cadastrados no CNPq que realizam pesquisa em ergonomia no Brasil.

\begin{tabular}{|c|c|c|}
\hline Grandes Áreas & Área do Grupo & TOTAL \\
\hline \multirow[t]{5}{*}{ Ciências Sociais Aplicadas (56) } & Desenho Industrial & 34 \\
\hline & Arquitetura e Urbanismo & 12 \\
\hline & Comunicação & 1 \\
\hline & Ciência da Informação & 3 \\
\hline & Ciência da Computação & 6 \\
\hline \multirow[t]{6}{*}{ Engenharias (58) } & Engenharia de Produção & 38 \\
\hline & Engenharia Civil & 8 \\
\hline & Engenharia Biomédica & 1 \\
\hline & Engenharia Elétrica & 4 \\
\hline & Engenharia Mecânica & 6 \\
\hline & Engenharia Sanitária & 1 \\
\hline \multirow[t]{2}{*}{ Ciências da Saúde (33) } & Fisioterapia & 20 \\
\hline & Educação Física & 13 \\
\hline Ciências Humanas (4) & Psicologia & 4 \\
\hline \multirow[t]{3}{*}{ Ciências Agrárias (12) } & Engenharia Agrícola & 7 \\
\hline & Agronomia & 1 \\
\hline & $\begin{array}{l}\text { Recursos Florestais e Engenharia } \\
\text { Florestal }\end{array}$ & 4 \\
\hline Linguística, Letras e Artes (2) & Artes & 2 \\
\hline Total Geral & & 165 \\
\hline
\end{tabular}


A partir do levantamento dos grupos de pesquisa cadastrados no CNPq, foi possível mapeá-los por regiões brasileiras. Na Região Sul estão presentes 64 grupos de pesquisa; na Região Sudeste, 58; na Região Nordeste, 34; na Região Centro-Oeste, 5; e na Região Norte, 4 grupos. Assim, é possível verificar que, embora os cursos de pós-graduação se concentrem nas Regiões Sudeste, Sul e Nordeste, os grupos de pesquisa estão distribuídos por todas as regiões do país, ainda que a distribuição não seja uniforme e muitos Estados não apresentem grupos de pesquisa nessa área.

Assim como os cursos de pós-graduação e os grupos de pesquisa, os eventos em ergonomia, como os organizados pela Associação Brasileira de Ergonomia (Abergo), constituem-se como importantes difusores de produção técnica e científica em ergonomia no país, o que é corroborado por Gomes et al. (2003). O primeiro evento na área foi o $1^{\circ}$ Seminário Brasileiro de Ergonomia, organizado em 1974 pela Associação Brasileira de Psicologia Aplicada em parceria com o Instituto Superior de Estudos e Pesquisas Psicossociais da Fundação Getulio Vargas. Já o primeiro evento efetivamente organizado pela Abergo foi o $2^{\circ}$ Seminário Brasileiro de Ergonomia, em 1984. Os trabalhos publicados nesses eventos constituem uma importante base de dados científicos de ergonomia.

No que se refere aos eventos científicos, vale destacar que a Abergo promove a realização do congresso que possui o mesmo nome da associação, além da revista Ação Ergonômica, portanto dois meios de divulgação da produção científica.

A partir da consulta nos Anais dos congressos da Abergo, verificou-se que no Abergo de 1999 foram publicados 191 artigos; no Abergo de 2000, 160; no Abergo de 2001, 146; e no Abergo de 2002, 277 artigos. A partir de 2004 os congressos passaram a ser bienais, e no Abergo de 2004 foram publicados 253 artigos; no Abergo de 2006, 228; e no Abergo de 2008, 298 artigos, totalizando 1.553 artigos ao longo desses anos.

O Congresso Internacional de Ergonomia e Usabilidade de Interfaces Humano-Tecnologia - Produtos, Programas, Informação, Ambiente Construído (Ergodesign) - e o Congresso Internacional de Ergonomia e Usabilidade, Design de Interfaces e Interação 
Humano-Computador (USIHC) são mais dois congressos que ocorrem simultaneamente e que se destacam na divulgação das pesquisas em ergonomia.

Segundo Campos et al. (2010), o Ergodesign contou com 499 trabalhos publicados até a edição de 2009, sendo que 3 deles não apresentam dados completos sobre origem. Os autores apresentam ainda uma análise das áreas de conhecimento e os temas abordados, além da distribuição geográfica e institucional.

A consulta nos Anais do USIHC não permite verificar a quantidade de artigos publicados em todos os eventos, pois não foi divulgada. Assim, são apresentados apenas os dados encontrados: no USIHC 2002 foram publicados 21 artigos; em 2003, 20; em 2005, 38; em 2006, 24; em 2007, 26; e em 2009, 29, totalizando 158 artigos.

Outros congressos como o Congresso Brasileiro de Pesquisa e Desenvolvimento em Design (P\&D Design) e o Congresso Internacional de Pesquisa em Design (Ciped), embora estes voltados para a pesquisa em design, também possuem temáticas para apresentação de trabalhos em ergonomia.

De acordo com Campos et al. (2010), no P\&D Design, ao longo das edições de 1994 a 2008, foram publicados 1.966 trabalhos, entre os quais 266 foram na área de ergonomia (13,73\%). Já no Ciped foram publicados 898 trabalhos em todas as suas edições, sendo 122 particularmente na área da ergonomia. Os autores analisam ainda a distribuição desses artigos relacionados ao tema ergonomia segundo área de abordagem (engenharia, design, outras), por tema (ergonomia de produto, ergonomia informacional, outros) e por região, Estado e instituição, o que demonstra uma ampla análise da produção científica da área da ergonomia, em dois dos principais congressos científicos da área do design.

\section{A criação da Abergo}

Um importante feito para a ergonomia brasileira foi a criação da Associação Brasileira de Ergonomia (Abergo). Em 13 de julho de 
1983, Itiro Iida, Anamaria de Moraes, Franco Lo Presti Seminério e Ued Martins Manjub Maluf firmaram a carta consulta sobre a criação da Associação nas dependências do Instituto Superior de Estudos e Pesquisas Psicossociais da Fundação Getulio Vargas (Moraes, 1999). Segundo a autora, a reunião constitutiva da Associação ocorreu em 31 de agosto de 1983, no auditório da Fundação Getulio Vargas, quando foi aprovada a denominação "Associação Brasileira de Ergonomia”. A data de sua fundação remete a 30 de novembro de 1983, quando foi criada a sigla Abergo, foi aprovado o Estatuto e foi eleita a primeira diretoria da Abergo, composta pelo professor Itiro Iida, como presidente, Reinier Rozestraten, como vice-presidente, Anamaria de Moraes, como diretora-administrativa, Leda Leal Ferreira, como diretora-financeira, e João Bezerra de Menezes, como diretor-técnico (Moraes, 1999).

É importante ressaltar que a Abergo, segundo Moraes (2004), foi aceita como membro da International Ergonomics Association em 1984. Entretanto, essa filiação nunca se concretizou por questões burocráticas.

\section{A certificação em ergonomia}

No congresso da Abergo de 2004, foi introduzido o Sistema de Certificação do Ergonomista Brasileiro (SisCEB), o qual concede o título de "Ergonomista Certificado" aos profissionais que se submetem ao processo. A certificação é uma tendência mundial e por isso recebe o apoio da International Ergonomics Association (IEA) e do Ministério do Trabalho e Emprego. Segundo Soares (2004), durante o período de 2002 a 2008, o Brasil foi o primeiro país da América Latina a emitir a certificação de ergonomistas.

\section{Discussão e considerações finais}

Ao mesmo tempo que o levantamento histórico da ergonomia no Brasil revela que uma investigação sobre ergonomia foi realizada 
no século XIX, com enfoque na antropometria, verificou-se que houve um longo período sem estudos nessa área. Somente a partir da década de 1970 pesquisadores de várias universidades brasileiras passam a introduzir a ergonomia no escopo dos estudos de diversas áreas do conhecimento.

Desse período em diante, a pesquisa em ergonomia vem se consolidando no país, porém ainda foi pequena a quantidade de livros produzidos no Brasil até o início da primeira década do século XXI. A razão dessa pequena produção de livros por autores brasileiros está relacionada ao fato de que efetivamente as pesquisas em ergonomia são recentes no país, visto que o primeiro trabalho publicado data de 1973.

Já os congressos de ergonomia têm contribuído significativamente para fazer a divulgação das pesquisas já desenvolvidas e em desenvolvimento pelos grupos de pesquisa e estudiosos da área, especialmente aquelas realizadas em programas de pós-graduação. Todavia, é oportuno ressaltar que o primeiro congresso de ergonomia ocorreu em setembro de 1974 - $1^{\circ}$ Seminário Brasileiro de Ergonomia - e foi considerado um marco para a história da ergonomia brasileira.

A ergonomia no Brasil viveu seu momento de destaque a partir da década de 1980, quando vários pesquisadores brasileiros retornaram da França após desenvolverem mestrado e doutorado, sob a orientação do professor Alain Wisner ou do professor Maurice de Montmollin, e ingressaram em universidades de vários Estados brasileiros, criando ou contribuindo para a realização de cursos de especialização em ergonomia. Sem dúvida esse fato contribuiu para a divulgação da ergonomia no país, bem como para despertar o interesse de pesquisadores que se envolveram com essa área de pesquisa na formação de novos ergonomistas.

Outro fator importante para o crescimento das pesquisas em ergonomia está relacionado à organização desses estudiosos e profissionais, que ocorreu com a criação da Associação Brasileira de Ergonomia (Abergo) em agosto de 1983. A Abergo passou a organizar congressos, uma forma de divulgar as pesquisas e de estabelecer 
um debate crítico sobre a produção científica entre pesquisadores nacionais e internacionais. Mais recentemente, em 2004, criou a Certificação para Ergonomistas, uma forma de incentivar a especialização na área para poder obtê-la.

O estudo em ergonomia se aplica às diversas áreas do conhecimento, por isso tem aumentado o número de estudiosos, no entanto ainda é necessário encontrar um meio de divulgação dos trabalhos que atinja um número maior de profissionais ligados a essa área de estudo, possibilitando tornar o conhecimento científico desenvolvido nessa área cada vez mais aplicado ao setor produtivo nacional.

\section{Referências bibliográficas}

BATEN, J.; PELGER, I.; TWRDEK, L. The anthropometric history of Argentina, Brazil and Peru during the 19th and early 20th century. Economics and Human Biology, v. 7, 2009, p.319-33.

CAMPOS, L. F. de A.; ANDRADE NETO, M. L. de; LANUTTI, J. N. de L.; SILVA, D. C.; PASCHOARELLI, L. C.; SILVA, J. C. P. da. A produção científica em ergonomia nos congressos de pesquisa em design no Brasil: um estudo bibliométrico. In: Ergodesign 2010, Rio de Janeiro. Anais... Salvador, 2010. CD-ROM.

CAMPOS, L. F. de A.; ANDRADE NETO, M. L. de; LANUTTI, J. N. de L.; SILVA, D. C.; PASCHOARELLI, L. C.; SILVA, J. C. P. da. Dez anos de ergodesign: reflexões sobre a produção científica em design ergonômico no Brasil. In: ERGODESIGN 2010, Rio de Janeiro. Anais... Salvador, 2010. CD-ROM.

FERREIRA, L. L.; DONATELLI, S. Ergonomia: o que há para ler em português. Revista Ação Ergonômica, v. 1, n. 2, dezembro de 2001, p.25-34. GOMES, J. O.; SOARES, M. M.; PATTERSON, E. L'analyse du travail: pratiques et reflexions de son utilisation au Brésil et aux États Unis. In: Congrès de La SELF, 38, Paris. Anais... Paris, 2003, 1 CD-ROM.

MORAES, A. Quando a primeira sociedade de ergonomia faz 50 anos, a IEA chega aos 40, a Associação Brasileira de Ergonomia debuta com 16. In: CONGRESSO BRASILEIRO DE ERGONOMIA, 9, Salvador. Anais... Salvador, 1999. 1 CD-ROM.

Uma contribuição à história da ergonomia brasileira. In: CONGRESSO BRASILEIRO DE ERGONOMIA, 13, Fortaleza, 2004. Anais... Fortaleza, 2004. 1 CD-ROM. 
MORAES, A.; SOARES, M. M. Ergonomia no Brasil e no mundo: um quadro, uma fotografia. Rio de Janeiro: Editora Univerta, 1989.

SCOTT, P. A. Ergonomics in Developing Regions: Needs and Applications. Boca Raton: Taylor \& Francis Group, 2009.

SOARES, M. M. 21 anos da ABERGO: a ergonomia brasileira atinge a sua maioridade. In: CONGRESSO BRASILEIRO DE ERGONOMIA, 13, 2004, Fortaleza. Anais... Fortaleza, 2004. 1 CD-ROM.

Breve história da ergonomia brasileira: da introdução da ergonomia no Brasil à produção, formação e certificação de ergonomistas. In: CONGRESSO INTERNACIONAL DE ERGONOMIA E USABILIDADE DE INTERFACES HUMANO-TECNOLOGIA, 5, 2005, Rio de Janeiro. Anais... Rio de Janeiro: PUC-Rio, 2005. 1 CD-ROM. Ergonomics in Latin America: Background, trends and challenges. Applied Ergonomics, v. 37, 2006, p.555-61. 


\author{
SOBRE O LIVRO \\ Formato: $14 \times 21 \mathrm{~cm}$ \\ Mancha: 23,7 x 42,5 paicas \\ Tipologia: Horley Old Style 10,5/14 \\ 1a edição: 2010 \\ EQUIPE DE REALIZAÇÃO \\ Coordenação Geral \\ Marcos Keith Takahashi
}

